DIW BERLIN

Discussion

Papers

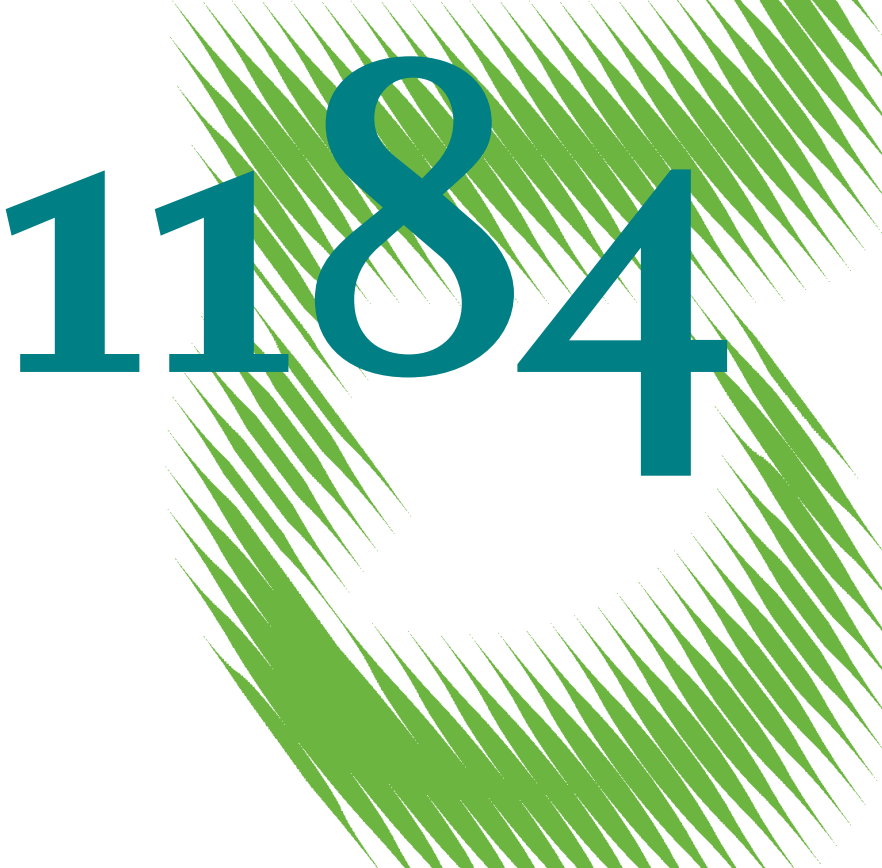

Who Starts a Business and Who Is Self-Employed in Germany 
Opinions expressed in this paper are those of the author(s) and do not necessarily reflect views of the institute.

IMPRESSUM

(C) DIW Berlin, 2012

DIW Berlin

German Institute for Economic Research

Mohrenstr. 58

10117 Berlin

Tel. $+49(30) 89789-0$

Fax +49 (30) $89789-200$

http://www.diw.de

ISSN print edition $1433-0210$

ISSN electronic edition 1619-4535

Papers can be downloaded free of charge from the DIW Berlin website:

http://www.diw.de/discussionpapers

Discussion Papers of DIW Berlin are indexed in RePEc and SSRN:

http://ideas.repec.org/s/diw/diwwpp.html

http://www.ssrn.com/link/DIW-Berlin-German-Inst-Econ-Res.html 


\title{
Who Starts a Business and who is Self-Employed in Germany ${ }^{1}$
}

\author{
Michael Fritsch ${ }^{2} \quad$ Alexander Kritikos $^{3} \quad$ Alina Rusakova $^{4}$
}

January 2012

\begin{abstract}
Based on representative data, the German Micro-Census, we provide an overview of the development of self-employment and entrepreneurship in Germany between 1991 and 2010, the first two decades after reunification. We investigate the socioeconomic background of these individuals, their education, previous employment status, and their income level. We observe a unique increase in self-employment in Germany by 40 percent which can partly be attributed to the transformation process of East Germany and to the shift to the service sector. We notice a yearly start-up rate of 1 percent among the working population (almost 20 percent of them being restarters), a decision that pays for the majority of individuals in terms of income. Contrary to other countries, in Germany there is a positive relationship between educational levels and the probability of starting a business.
\end{abstract}

Keywords: $\quad$ Entrepreneurship, Self-Employment, Start-ups, Germany JEL classification: L26, D22

\footnotetext{
${ }^{1}$ We are indebted to the Research Data Centre of the Regional Statistical Office of Thuringia in Erfurt for support and cooperation and we are grateful to Roy Thurik for his ideas on an early draft of the paper.

${ }^{2}$ Michael Fritsch is Chair of Business Dynamics, Innovation, and Economic Change at the Friedrich Schiller University Jena and Research Professor at the German Institute for Economic Research (DIW Berlin); e-mail: m.fritsch@uni-jena.de.

${ }^{3}$ Alexander Kritikos is Research Director at the German Institute for Economic Research (DIW Berlin), Professor of Economics at the University of Potsdam, and Research Fellow of the IZA, Bonn and of the IAB, Nuremberg, e-mail: akritikos@diw.de.

${ }^{4}$ Alina Rusakova is Research Associate at the Chair of Business Dynamics, Innovation, and Economic Change at the Friedrich Schiller University Jena, e-mail: alina.rusakova@uni-jena.de.
} 


\section{Introduction}

German policy makers started in the mid Nineteen Eighties campaigns to promote a new entrepreneurial culture in Germany. For good reasons: New business formation and entrepreneurial activities are supposed to be one important driver of economic dynamics and of job creation (for an overview see Fritsch, 2011). Without an inflow of new entrepreneurs and the businesses these individuals start, economies can stagnate. Therefore, several (certainly not all) researchers regard new business formation as a main source of innovation and growth (Schumpeter, 1939; Audretsch, 2007). One generation later, we observe in Germany a unique development that we examine in this paper: Between 1991 and 2009 the number of self-employed persons increased by 40 percent - a magnitude of change that did rarely occur in other established innovation driven economies. During this period, German policy toward entrepreneurship made also several radical changes. For instance, in 2000 the Federal Ministry of Labor increased its spending to around 750 million Euros for the bridging allowance, a program that aims to bridge the initial months of selfemployment by providing lump sum payments to business founders who were previously "unemployed". In 2003, the government introduced a second support program for new businesses set up by unemployed, the start-up subsidy, and increased its spending in 2005 to 3.2 Billion Euros. In 2007 it merged the two programs into one, the start-up allowance. For 2013, the government decided to reduce the available budget for this program from 1.8 billion (the estimated spending in 2011) to 470 million Euros, although several evaluation studies have shown that this kind of support scheme is highly successful (see e.g. Caliendo and Künn, 2011, Kritikos, 2011).

Beyond the evidence of the substantial increase of self-employment in Germany, there is little reliable information about this development. Who are the self-employed and business founders and what is their socio-economic and educational background, their previous working experience and are they successful with their ventures in terms of income generation? To some extent, the fact that there are no reliable answers to these questions, might explain why German entrepreneurship policy lacks clear orientation.

For Germany there are more than half a dozen data sources claiming to reveal how many people start businesses in Germany each year. The respective figures are diverse. Take as an example the year 2003: the business founder panel of Center for European Economic Research (ZEW) counted 243,000 business founders, the 
German Micro-Census, a representative sample, reported 327,000 business founders, and the Start-up Monitor of the state owned bank "Kreditanstalt für Wiederaufbau" (KfW) declared that there were 1.65 million business founders that very same year. Thus, start-ups figures diverge almost by the factor of seven. The reason for these differences is that all German statistics usable as sources of information on the number of start-ups suffer from either under- or over-estimation (see also Fritsch, et al., 2003). ${ }^{5}$

Based on the most reliable source, the German Micro-Census, this paper sheds more light on entrepreneurship in Germany and its development since reunification. In particular, we provide an overview of the demographic, economic, sectoral and educational background of the business founders and the self-employed. As the group of self-employed is very heterogeneous, we will also perform several analyses for subgroups. Based on these facts, we further analyze the particular relationships between age, education and the probability of starting an own business. By conducting a multivariate analysis, we also provide answers to the question which variables increase the probability of being self-employed thus partly explaining the increase in self-employment. Last but not least, we investigate the income development of entrepreneurs in the first three years after the start-up decision, a controversially discussed topic, also in Germany.

The remainder of this paper is organized as follows: As all existing data sources on self-employment and on start-up activities have shortcomings, we will present in Section 2 an overview over advantages and disadvantages of the most important data sources. Given that we chose the German Micro-Census for our analysis, Section 3 gives a further description of this source with a special focus on information about self-employment. Section 4 describes the development of self-employment and of business formation in the period between 1991 and 2009 and answers the crucial question who the self-employed persons are, where they are coming from and how their income develops. In this section we also analyze the relationship between age and the start-up probability as well as between educational levels and the start-up probability. In Section 5, we present a logit estimate revealing which variables influence self-employment at the beginning and the end of the observation period. We conclude in Section 6 with some policy implications.

\footnotetext{
${ }^{5}$ In other countries, such as Sweden, the US and a number of further countries, the most informative source about the characteristics of entrepreneurs is the 'Panel Studies of Entrepreneurial Dynamics' (PSED) (see Davidsson, 2006; Reynolds, 2007). However, the PSED studies also have a number of serious shortcomings (Parker and Belghitar, 2006).
} 


\section{Review of data sources on self-employment activities in Germany}

In this section we review the existing reporting systems that generate information about business formation and self-employment on a regular basis. Several new data sources have been developed, all aiming to capture and describe the start-up dynamics in Germany. In 1998 the Global Entrepreneurship Monitor was launched, followed in 2000 by the "Gründungsmonitor" developed by the state-owned bank "Kreditanstalt für Wiederaufbau" (KfW) as well as by several further reports introduced by the association of the Chambers of Commerce. Besides the MicroCensus, which delivers data for West- and East-Germany since 1991, basic data of yearly start-ups are also provided by two more sources, namely by the Institute for Small Business Research (Institut für Mittelstandsforschung - IfM) in its present form since 1996 and by the Center for European Economic Research (Zentrum für Europäische Wirtschaftsforschung - ZEW) since 1991. All data sources use different methods of data collection, different definitions of what constitutes a business foundation, and different questions to find start-up activities. We compare the following six data sources, which all systematically and annually address issues of entrepreneurship: ${ }^{6}$

- German Micro-Census

- IfM Start-up statistics

- Business registration statistics (Gewerbeanzeigenstatistik)

- KfW Start-Up Monitor

- Global Entrepreneurship Monitor (GEM)

- ZEW Founder Panels

The requirements for data sources to allow an analysis of business formation as well as self-employment activities in Germany are the following: i) a complete inventory count or representativeness of data avoiding over- and under-estimation of start-ups and of self-employment in all sectors of the private economy; ii) information on entries into self-employment and on the stock of self-employed; and iii) rich socio-

\footnotetext{
${ }^{6}$ Other sources such as the social employment statistics, the value-added-tax-statistics, the enterprise register system or the start-up report of the chambers of commerce are not presented here for obvious reasons. All these sources have data problems leading to under- or overreporting of start-ups in a more systematic way than the other sources presented in this section. More information is available from the authors upon request.
} 
economic background information. Moreover, it would be desirable, iv) to have longitudinal information that follows firms and individuals over time.

The German Micro-Census, collected by the Federal Statistical Office, is the largest annual representative household survey in Europe with a general sampling fraction of 1 percent of the total population living in Germany providing information about 820,000 individuals in each wave (Statistisches Bundesamt, 2009). Selfemployment and transitions into it are gathered through a yearly question on the primary employment activities. The representative nature of the Micro-Census makes it possible to differentiate self-employment activities by a number of indicators, such as demographics, industrial and occupational sector, regional distribution, and others. It allows the analyzing of the short-term dynamics of entrepreneurial activities in Germany with its two panel waves of four years. Moreover, since it is obligatory to participate in the Micro-Census and to respond to most of the questions, problems caused by missing values are largely irrelevant in this statistics.

Main disadvantages of the Micro-Census are that it does not contain a sufficient number of observations for an analysis at regional levels below the level of Federal States and that it only partly reveals the number of individuals who start selfemployment as secondary activity (while it captures all secondary activities in the stock data). Moreover, until 2004, the survey design of the Micro-Census was characterized by a fixed reference week, which means that the self-employment status referred to a single reference week per year. Consequently, the statistics do not capture those business founders who entered self-employment and exited again between two waves. Overall, the Micro-Census can be regarded as an appropriate data source for the analysis of self-employment in Germany.

The IfM start-up statistics and the business registration statistics (which can be jointly presented as they make use of the same data source) are based on a different approach. They count the notifications of business activities in the business register (Günterberg, 2009), and are, in contrast to the Micro-Census, a complete inventory count. Since the IfM filters out relocations and changes of corporate forms, the IfM data is, to a certain extent, more precise than the statistics of the business register. In addition the IfM deducts 10 percent of all notifications from the complete statistics as it is argued that there is a certain share of "artificial or fake notifications" (such as fictitious business foundations, multiple notifications etc.) in the basic statistic data (Clemens and Kayser, 2001).

The source has several disadvantages. First, it is argued that the share of false notifications is greater than 10 percent and that there is no filter that can help identify 
these cases. Secondly, professionals and freelancers are not covered by this data source as they are not required to register, which is estimated to account for about $25 \%$ of all start-ups. ${ }^{7}$ Combined, these two problems simultaneously suggest both underestimation and overestimation of the number of start-ups. Nevertheless, it is argued that start-ups are overestimated in this source. ${ }^{8}$ Third, this data source contains limited socio-economic information and, fourth, it just measures entries (and, to a limited extent, exits) but no stock of self-employed and, fourth, it is purely cross-sectional such that it is impossible to follow firms or individuals over time. For the year 2003, the year discussed in section 1, the IfM reported 509,000 entries after cleaning the data, while the business registration statistics observed 720,000 notifications from the same source (see IfM, 2004, Statistisches Bundesamt, 2004).

The KfW-Start-Up Monitor (KfW, 2009), mentioned in the introduction, is an annual population survey. At the moment about 50,000 German residents at age between 14 and 65 years were interviewed with the primary purpose of getting information on start-up activities in Germany. The telephone survey includes questions concerning whether or not the respondent became self-employed in a primary or secondary activity over the previous 12 months. Additionally, information about socio-economic and financial variables is collected. The KfW data are the only data besides the Micro-Census that provides information about start-ups by the unemployed. Based on these data, the KfW extrapolates the full amount of start-ups every year in primary and secondary employment.

While the rich socio-economic data of this source is appealing, it contains severe limitations. First, this monitor publishes only information about entries into selfemployment but not about the stock of self-employed. Second, the data source has certain problems to prove its representativeness. ${ }^{9}$ Thirdly, and related to the second point, these data overestimate the number of start-ups. A single question in a telephone interview about start-up activities is probably too imprecise with respect to several issues, such as when exactly the business was started, or the self-

\footnotetext{
${ }^{7}$ See Oberlander, 2004. Unfortunately, there are no statistics for start-up activities of professionals.

${ }^{8}$ See Fritsch, et al., 2002.

${ }^{9}$ Non-representativeness can be proved for instance with regard to the data for the years 2003 and 2004 where we have information about two different start-up schemes, which then existed. In 2003 , 158,000 persons used the so called bridging allowance and 97,300 persons the start-up subsidy. For this year the KfW Start-Up Monitor contains 119 persons who made use of the bridging allowance and only 18 persons who made use of the start-up subsidy. A t-test shows a rejection of the hypothesis that the KfW start-up monitor is representative. The same holds for the year 2004. Exact calculations are available from the authors on request.
} 
identification as nascent entrepreneur. The extent of overestimation of selfemployment in this source can be illustrated for the same year 2003 for that the KfW reports almost 1 million entries into self-employment as a secondary employment (KfW, 2005). The Micro-Census reports for the same year a stock of little more than 400,000 persons who were self-employed in secondary employment. The KfW had more than double as many entries into this kind of activity as the Micro-Census observed in the stock data.

The Global Entrepreneurship Monitor (GEM) was established specifically to facilitate cross-national comparisons of entrepreneurial activities. It conducts an annual survey of entrepreneurial attitudes of the adult population in 42 countries, including Germany (for an overview see Reynolds, 2005). Each year approximately 7,500 German residents between 18 and 64 are interviewed via a telephone survey. The interview includes five questions about self-employment activities over the previous 3.5 years. This source is based on a small survey sample as only about 2 percent of the interviewed individuals (i.e around 150 persons) have started a business, provides also only restricted information about the socio-economic status of respondents, and lacks an annual focus, unlike the other sources, while gathering information about both planned and actual start-up activities over the 3.5 years prior to questioning. The stock of self-employed individuals is not the focus of this data source. The GEM reports 1.6 million entrepreneurs in Germany in 2003, among them nascent entrepreneurs, as well as those individuals who have set up a business within the previous 3.5 years, a completely different account to the $\mathrm{KfW}$, which found 1.65 million start-ups within the previous year (Brixy et al., 2009).

Since the reporting unit of the ZEW Founder Panel (see Almus, Engel and Prantl, 2000) is not the entrepreneur but the respective company, this source contains no socio-demographic information about the founders. Nevertheless, the source is interesting insofar as it counts all start-up companies that either signed up in any commercial or associations register, or whose owners asked for commercial loans. Due to the longitudinal character of this data base, the development of the firms can be followed over time. Thus, this source can be seen as providing complete information on "economically active companies". However, small companies (usually solo-entrepreneurs) and liberal professions are underrepresented.

Keeping in mind the requirements for a data source to be useful for our analysis, we conclude that no data source completely fulfills all four points. However, the German Micro-Census meets most of the requirements to a sufficient degree. Moreover, this data source provides an exact picture of self-employment, as 
differentiated by a number of demographic, socio-economic, as well as regional characteristics of self-employed individuals.

One caveat is the systematic under-estimation of short-term start-up activities (shorter than one year) and part-time business founders. This may explain why this data source finds significantly fewer entries into self-employment than the IfM Startup statistics. A second caveat, which is shared not only by the Micro-Census but by all data sources, is the incomplete (if not missing) information about start-ups out of unemployment in relation to the total number of start-ups. ${ }^{10}$ Since all other available data sources have either no information on the stock of self-employed or no information on socio-economic characteristics, and are either non-representative or face more severe over- and underestimation problems, we conclude that the MicroCensus is the best data source to analyze the questions we proposed in section 1.

Interestingly, there are few studies investigating the issue of self-employment on the basis of the Micro-Census. Among them, Piorkowsky et al. (2009) provided a description of the development of self-employment in Germany between 1997 and 2007, concentrating on self-employment activities by the German population and on the distribution of self-employment by gender. Boegenhold and Fachinger (2007) use the Micro-Census data for the analysis of solo-entrepreneurs.

\section{Data: The German Micro-Census}

The German Micro-Census ${ }^{11},{ }^{12}$ is a representative survey containing socio-economic information about approximately 820,000 individuals living in 380,000 households in

\footnotetext{
${ }^{10}$ Only two data sets have the potential to answer this question: the KfW data provide direct evidence for start-ups out of unemployment, but suffers the problem of non-representative data (as shown in the previous footnote). The Micro-Census has also information about the employment status of selfemployed in the previous year. However, a large number of start-ups experience unemployment for less than twelve months which is why the number of start-ups out of unemployment is not exactly captured in the Micro-Census.

${ }^{11}$ Data access was provided on-site in the Federal Statistical Office in Erfurt, Thuringia.

${ }^{12}$ The legal foundations for the conduction of the German Micro-Census are stated in the MicroCensus Law with a limited period of validity. During the time period from 1991 to 2009, which is used for the analysis in the present paper, three Micro-Census Laws were in force. Until 1996, the MicroCensus statistics were conducted and processed according to the Micro-Census Law 1985 (MicroCensus Law 1985; Federal Law Journal I, p. 955) and its modification from 1990 (Federal Law Journal I, p. 2837). In 1996, the former Micro-Census Law 1985 was replaced with the Micro-Census Law 1996 (Micro-Census Law 1996; Federal Law Journal I, p. 34) which, in turn, was replaced in 2004 by the Micro-Census Law 2005 (Micro-Census Law 2005; Federal Law Journal I, p. 1350). The MicroCensus Law 2005 is in force through 2012.
} 
Germany. ${ }^{13}$ As each member of a randomly selected household in the Micro-Census is obliged to provide information for most of the questions, the non-responses is rather small at about 5 percent. ${ }^{14}$ Our analysis draws on 19 waves of the MicroCensus, starting with 1991, when the sample has been substantially enlarged, through the 2009 wave, the most recently available data at the time of this analysis. We employ two measures of entrepreneurship: self-employment and the foundation of a business. ${ }^{15}$ Additionally, we consider the subgroups of the solo-entrepreneurs and of the self-employed who have at least one employee.

The classification of individuals as self-employed is based on a survey question about the employment status of the respondents. Self-employment as an employment status applies to those individuals who own a business, including selfemployed craftsmen as well as professionals and freelancers. We identify business founders by using the responses to the question about the beginning of the present employment. ${ }^{16}$ Those who became self-employed in the time period between the last and the present surveys ${ }^{17}$ are classified as business founders. The German MicroCensus distinguishes between self-employed individuals without employees and selfemployed individuals with employees. While the latter category implies that a

\footnotetext{
${ }^{13}$ The Micro-Census was started in 1957 as an annual survey of private households and persons in West Germany and was expanded to include former East German states in 1991. The central aim of this study is to collect nationally representative micro-data about the population structure, economic and social situation of individuals and households, labor activity, education, as well as living conditions and health. The Micro-Census includes most of the attributes of the European Union Labor Force Survey (EU-LFS) and allows comparing the data on employment activities among EU member states. A stable set of core questions appears every year, covering most essential areas, such as population and demography; education, training, and qualification; labor market and occupational dynamics; income.

${ }^{14}$ The Micro-Census panel is slightly affected by an attrition problem, as individuals who moved out of surveyed households during the observation period are not traced.

${ }^{15}$ The Micro-Census does not contain information about the number of founders in a firm meaning that we cannot make any reliable statement about the number of firms established. Hence, the definition of "business founders" should be understood in terms of changing one's employment status to selfemployment within the last wave.

${ }^{16}$ The corresponding question in the Micro-Census was introduced in 1996 as: "In which year and in which month did you start your present employment as employee or self-employed?" For previous waves we are not able to identify transitions into self-employment. Remarkably, from the wave 2005 onwards, the Micro-Census was redesigned in a way that the precise date of start-up activities could only be recorded within a three month period instead of one specific month, as was the case during previous Micro-Census surveys. Consequently, the identification of start-ups is less precise after 2005.

${ }^{17}$ Until 2005 the Micro-Census surveys had been conducted each year in April. From the year 2005 on the data are gathered over the whole year. Hence, after the year 2005 the time period for identifying a start-up may be shorter or longer than three months. In the available data we can only identify which quarter of the year the individual was surveyed.
} 
business owner has employed at least one paid worker, self-employed individuals who employ unpaid family workers fall into the former category. In the current study we address those individuals who start a business in their main occupation and do not consider those who are involved into venturing a business as a secondary activity. All individuals are assigned to their main residence at the time of the survey. In addition, by calculating the rates, we restrict the sample to individuals aged between 18 and 65 years and exclude those in military or civilian service, and professional soldiers. The individuals excluded presumably have a limited occupational choice set, or different determinants of occupational choice that could distort our analysis.

Key to our analysis are the basic socio-economic variables as well as variables on educational background and current working experience that were included in each wave of the Micro-Census that we consider in this study. In particular, we display detailed information on the individual's highest level of education, the current employment status, and the industry sector of employed people. Furthermore, information on an individual's net income as well as standard demographic characteristics such as gender, age, marital status and nationality are also provided in each wave of the Micro-Census.

The German Micro-Census provides certain possibilities to follow individuals over time. For a more detailed analysis, we use a panel data set based on the crosssections of Micro-Census. The generation of these panel data is possible because the selection of respondents follows a partial rotation procedure according to which all households in the sample are surveyed over a period of four consecutive years. Each year, about 25 percent of the households are substituted by new respondents. Hence, it is possible to generate four year panel data sets, which contain approximately 25 percent of the respondents in each wave. The Statistical Office provides two panel data sets for time spans from 1996 until 1999 and 2001 until 2004. In this paper we use the latest available panel data set for the period 20012004. The Micro-Census panel data includes most of the variables from the original survey program and allows us to analyze the development of start-ups over a period of up to three years. 


\section{Description of entrepreneurial activities in Germany}

\subsection{Self-employment and new business formation 1991 - 2009}

Between 1991 and 2009 the number of self-employed persons in the German population rose almost constantly from 3.037 million in 1991 up to 4.215 million in 2009, an increase of almost 40 percent (see Figure 1 and Table A1 in the Appendix). Only in 2001 and 2008, probably due to the economic crisis during these two years, there were small downturns in the self-employment activities. At the beginning of the observation period in 1991, two years after the break down of the GDR, the selfemployment rate ${ }^{18}$ in East Germany was already 5.1 percent. According to Kawka (2007), self-employment activities in the GDR, in 1989, were 1.8 percent of the

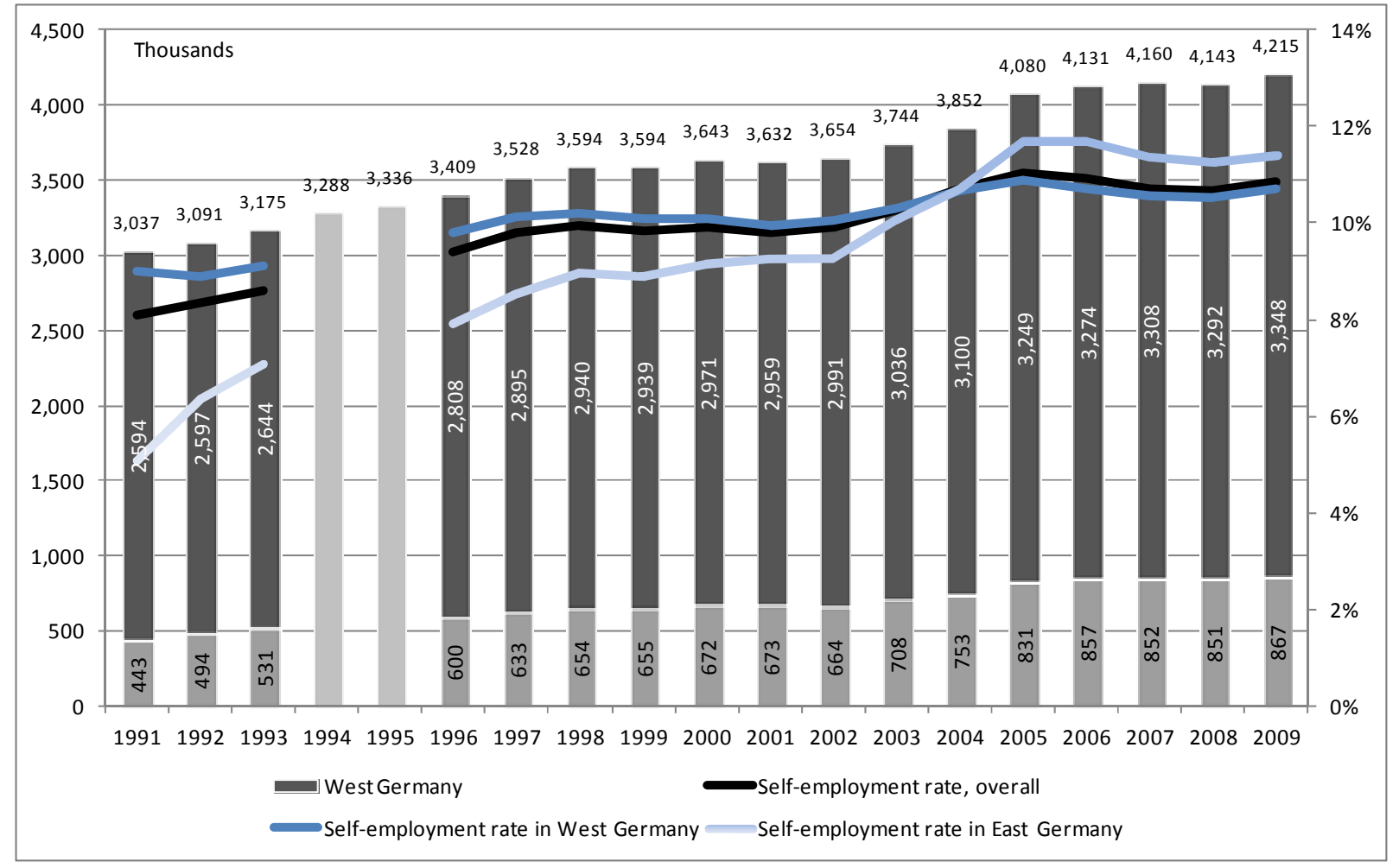

Figure 1: Self-employed individuals, absolute numbers and self-employment rates, 1991-2009

\footnotetext{
${ }^{18}$ Self-employment rates are calculated as the ratio of self-employed individuals in age between 18 and 65 with the employed population (dependently- and self-employed) in the same age category, excluding professional soldiers, and those in military service or civilian service.
} 
working population, constituting an initial jump-start of the subsequent rise of selfemployment activities in East Germany immediately following reunification. In the following years, through 2004, the dynamics of self-employment rates show convergence of the East to the West German share; and after 2004 the selfemployment rate in East Germany was greater than West German levels.

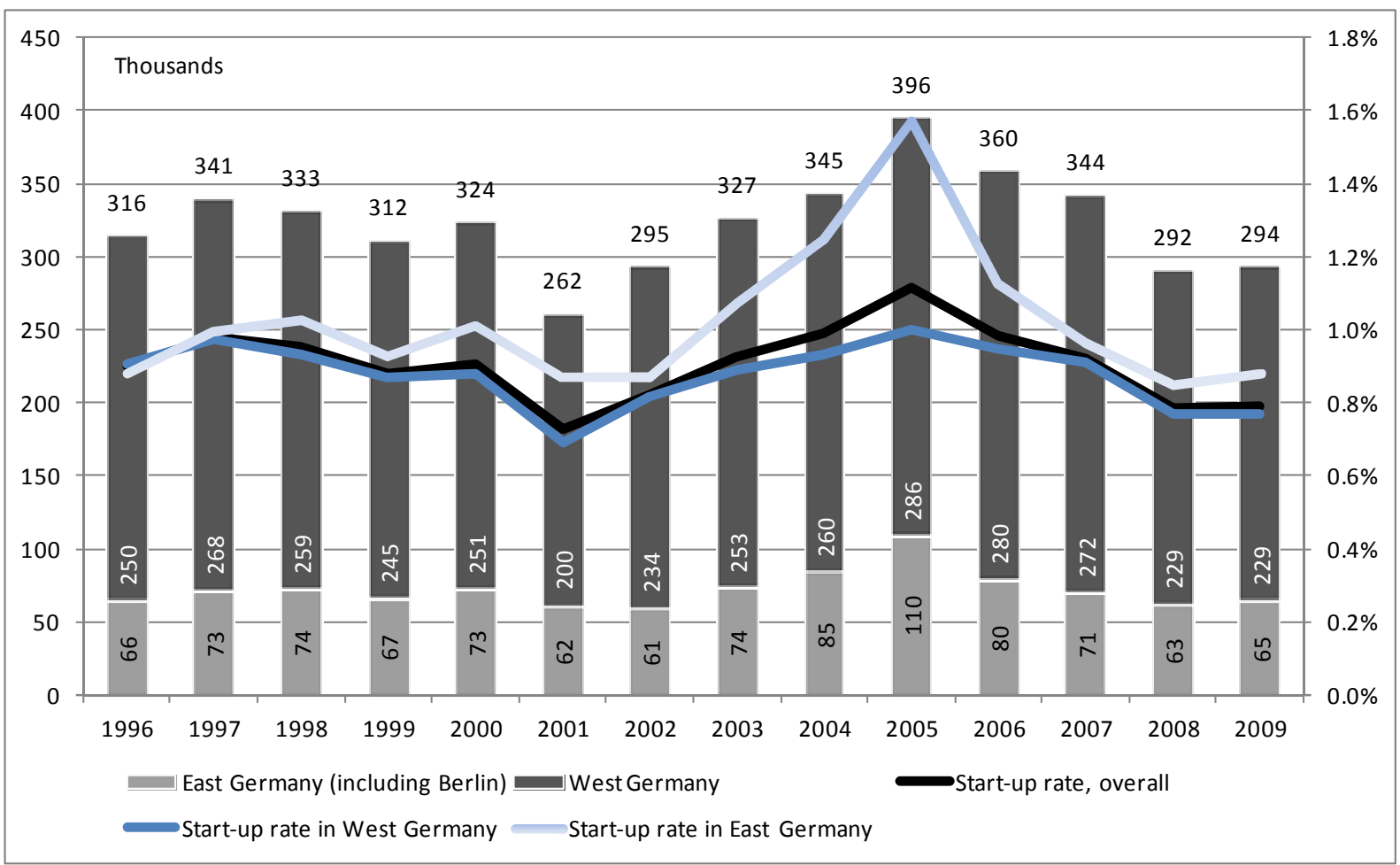

Figure 2: Entries into self-employment, absolute numbers and start-up rates, 19962009

While the number of self-employed individuals grew steadily over the observation period, the number of business founders shows some volatility (Figure 2). Starting with more than 300,000 transitions into self-employment (as a primary activity) between 1996 and 2000, and after a certain decline in 2001, in the following years, the number of business founders increased up to 396,000 in 2005. In this period the support of start-ups out of unemployment was substantially expanded. A turnaround was observed in 2006 with a decrease to fewer than 300,000 business founders in 2008 and 2009. During this time period a re-reform of the start-up subsidies in the other direction (see Caliendo und Kritikos, 2009) and another economic crisis occurred. Differentiating the development of start-up rates between West and East 
Germany shows, that start-up activities in East Germany exceeded those in West Germany in the late 1990s, and remained, since then, higher than in West Germany.

Thus, the self-employment rate in Germany is increasing over the observation period. Starting at around 8 percent in 1991, the self-employment rate increased to 11 percent in 2009, while the average annual share of business founders is fluctuating around 1 percent of the working population. Finally, given that the start-up rates in East Germany are constantly higher than in West-Germany the selfemployment rate in East Germany converged toward the West-German rate and since 2004 it even exceeds the West German level.

\subsection{Self-employed and business founders by employer status}

Start-ups that have employees do not only create jobs for persons other than the entrepreneurs themselves. They also tend to have better prospects in the market (Geroski, 1995). In Germany there is an increasing number of individuals acting as solo-entrepreneurs, i.e. no workers are hired (see Figure 3). In 2004 the selfemployment rate of self-employed without employees was 3.7 percent, increasing to

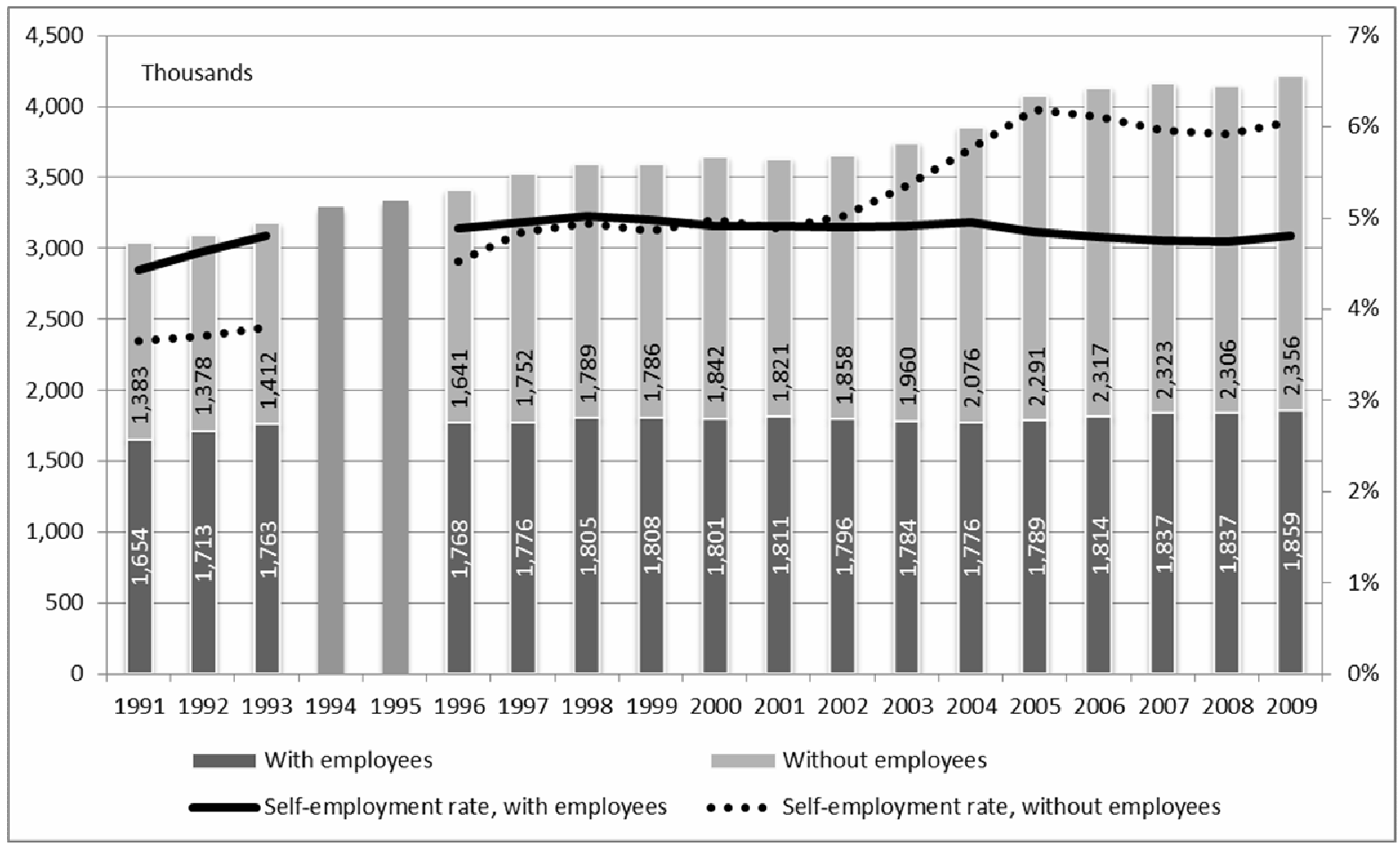

Figure 3: Self-employed individuals with and without employees, absolute numbers and self-employment rates, 1991-2009 
6.1 percent in 2009. The self-employment rate of self-employed with employees remained more constant at about 5 percent over that period.

The start-up rate for solo founders increased from 0.6 percent in 1996 to 0.9 percent in 2005, and subsequently decreased back to the initial level by 2009 (see Figure 4). It is quite remarkable that the numbers of solo business founders reflect the overall trend of start-up activities in Germany, as depicted on Figure 2. The bad news is that the start-up rate of business founders with employees declines from 0.3 to 0.2 percent during that period (see Table A2 in the Appendix for details).

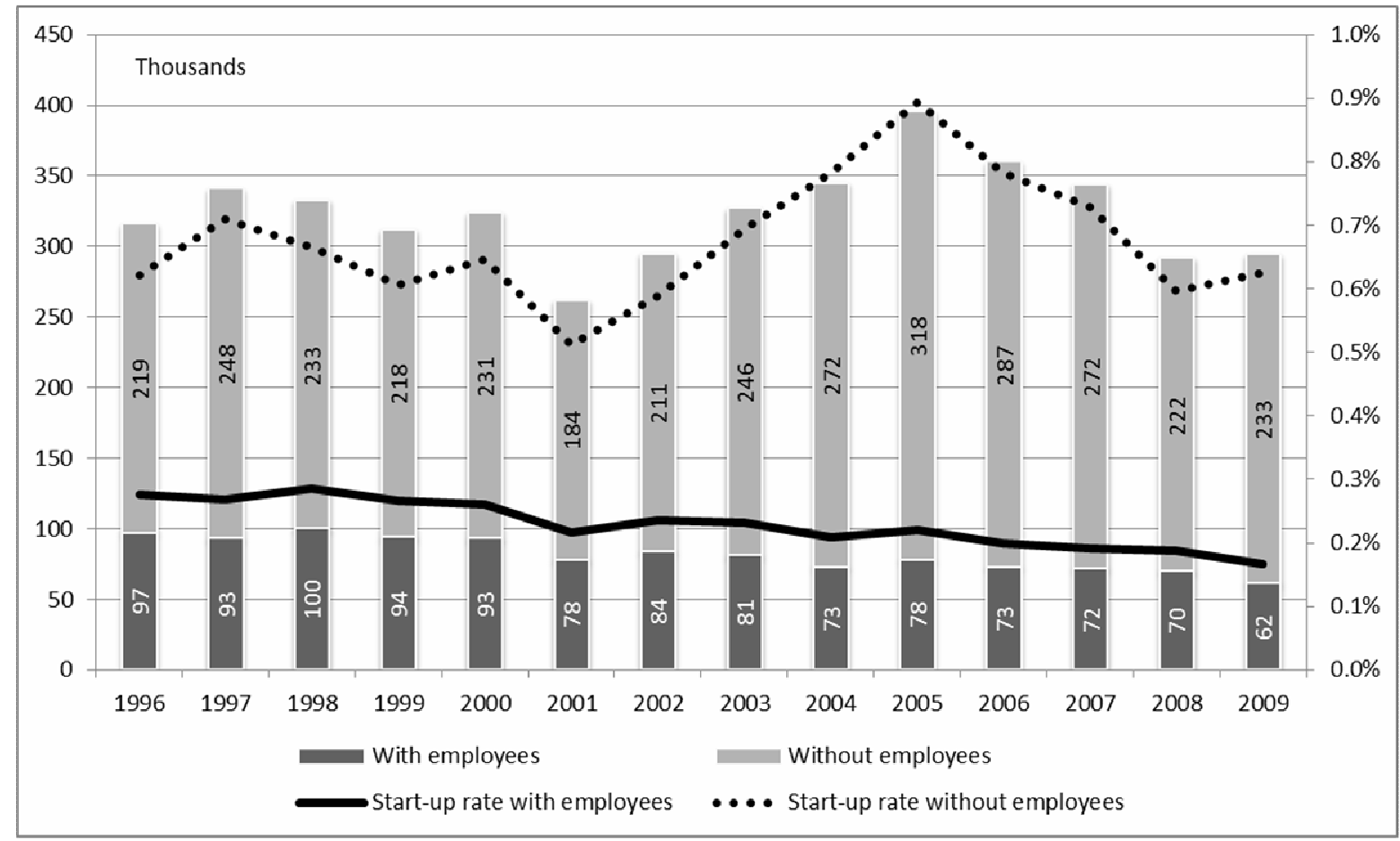

Figure 4: New business founders with and without employees, absolute numbers and start-up rates, 1996-2009

\subsection{Self-employed and business founders by industry sectors}

The industry structure of self-employment changed substantially over the observation period (see Figures 5 and Table A3) ${ }^{19}$. In line with the general trend, the prevalence of self-employment in services became more pronounced over time: the overall contribution of self-employed to this sector (including credit and insurance and transport, and communication) increased from 35.8 percent in the year 1991 to 52.9

\footnotetext{
${ }^{19}$ Industrial sectors are defined as Wirtschaftsunterbereiche of the Klassifikation der Wirtschaftszweige (see Statistisches Bundesamt, 2003).
} 
percent in the year 2009 reflecting the structural change observed in all innovationdriven economies. Most other sectors faced negative trends, such as "mining, manufacturing, energy and water supply," which almost halved to 8.3 percent in 2009; or "agriculture and forestry," which decreased from 13.6 percent in 1991 to 6.5 percent in 2009. Only in one other sector, "construction", did the number of selfemployed increase: from 8 percent in 1991 to 11.2 percent in 2009.

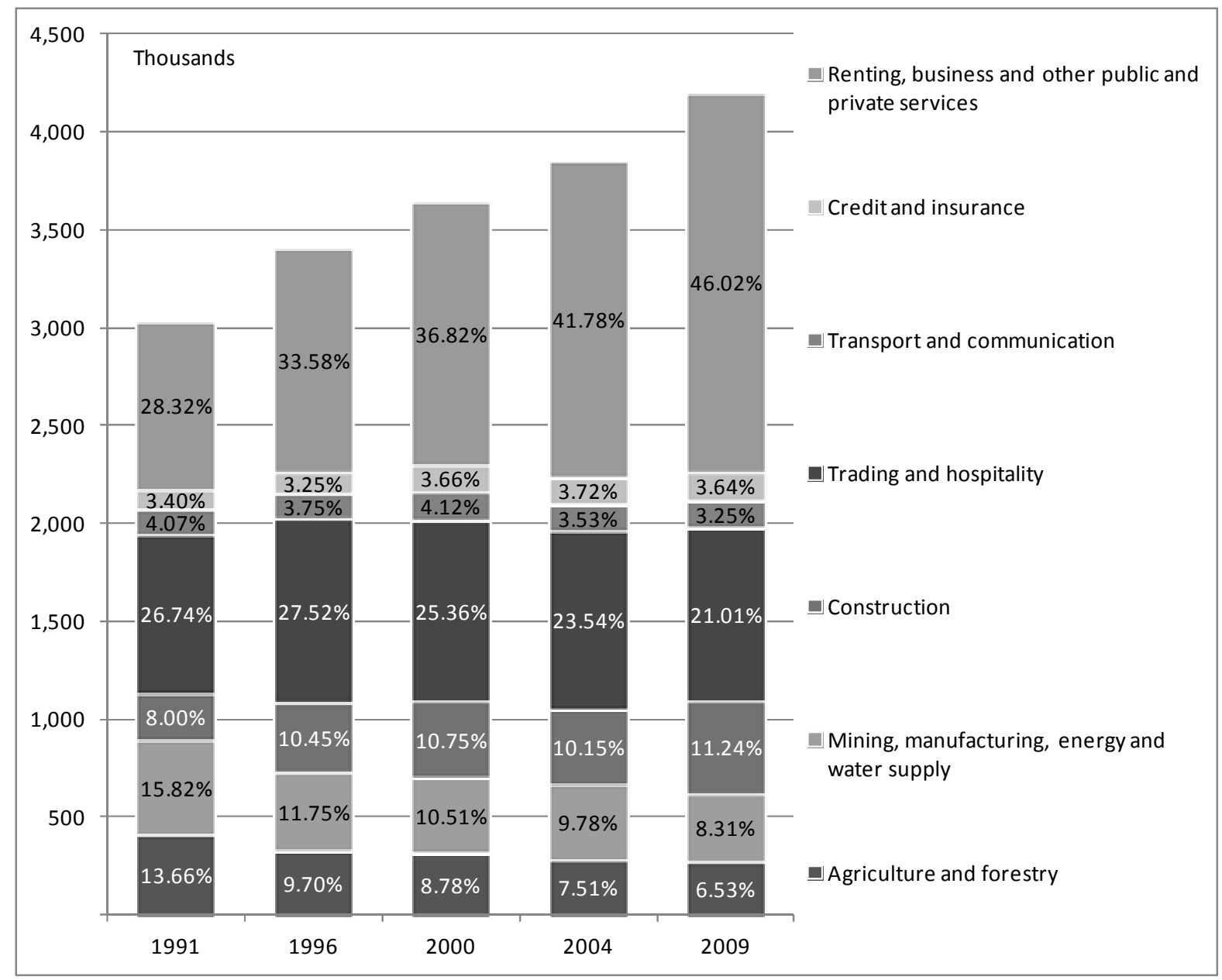

Figure 5: Self-employment by industrial sectors, absolute numbers and shares, 1991 2009

The development of business formation by industry reveals a slightly different picture (see Figure 6). Besides the service sector the shares of business founders in all other sectors declined to various extents. The percentage of business founders in services jumped from 46.2 percent in 1996 to 60.4 percent in 2009, meaning that 


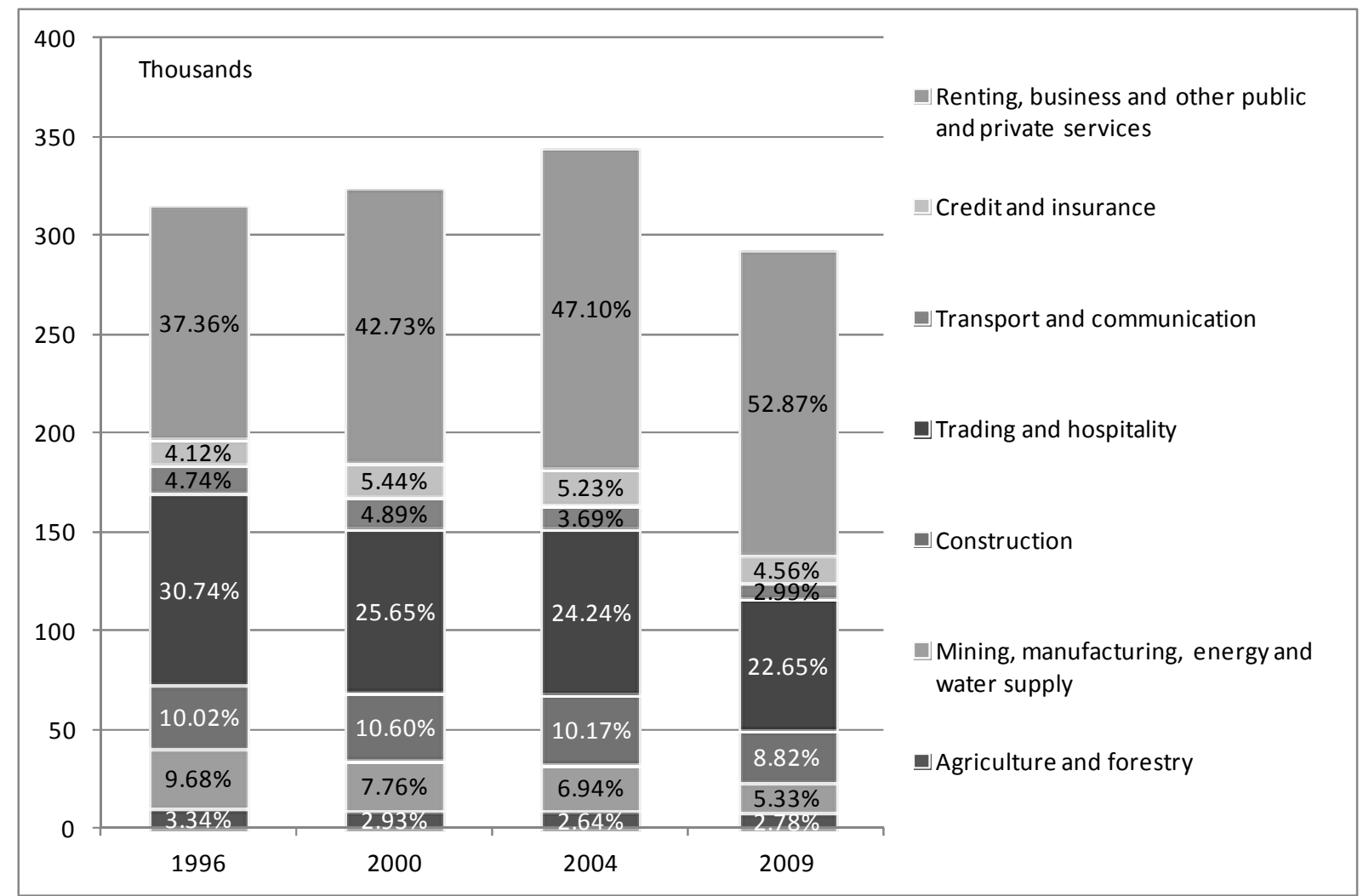

Figure 6: New business founders by industrial sectors, absolute numbers and shares, 1996-2009

among all business founders, most individuals start in the service sector. The largest decrease in the shares of business founders was in "trading and hospitality" (by 8.1 percentage points) and "mining, manufacturing, energy and water supply" (by 4.4 percentage points).

\subsection{Demographic characteristics of self-employed}

\subsubsection{Age structure}

Entrepreneurs in Germany have become older during the time under study (Figure 7). While the share of self-employed persons in the youngest age cohort (below 25 years) and the second youngest group (between 25 and 34 years) decreased from more than 21 percentage in 1991 to 14 percentage in 2009, the share of selfemployed persons in all cohorts above than 34 years grew over the observation period. Remarkable is that the share of self-employed in the oldest cohort (65 years and older) increased to 6.2 percent in 2009. Like the self-employed, the population of 
dependently employed persons experienced a process of aging during the period of analysis (Table A4). The age distribution of self-employed persons is, however, more skewed toward older ages as compared to the distribution of the dependently employed.

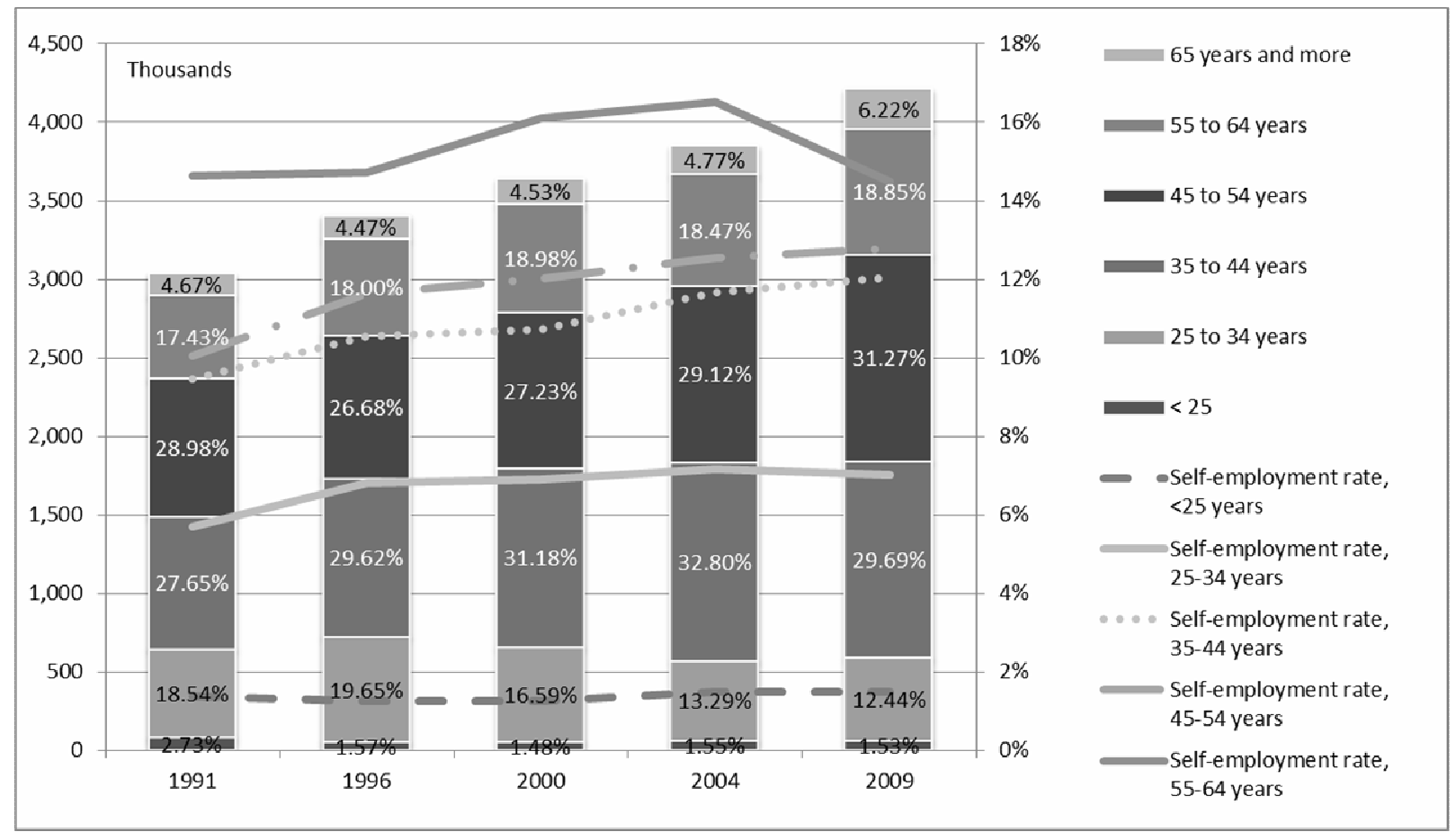

Figure 7: Self-employment and age structure, absolute numbers, shares, and cohort-specific self-employment rates, 1991-2009

The picture looks slightly different when considering the cohort-specific selfemployment rates calculated as the number of self-employed over the number of all employed individuals in the same age cohort. For instance, the self-employment rate in the youngest cohort (below 25 years) remained at a constant level of 1.5 percent over the period between 1991 and 2009. There is a slight increase from 6 to 7 percent in the willingness to be self-employed in the second youngest cohort of those between 25 and 34 years old. The next two age groups, those between 35-44 years and between age 45 and 54 show stronger increase of the self-employment rate from 9.5 to 12 percent and from 10 to 13 percent, respectively. In the oldest age cohort (65 years and older, not depicted in Figure 7) the self-employment rate is highest though it decreased from 44.4 percent in 1991 to 39.2 percent in 2009. 


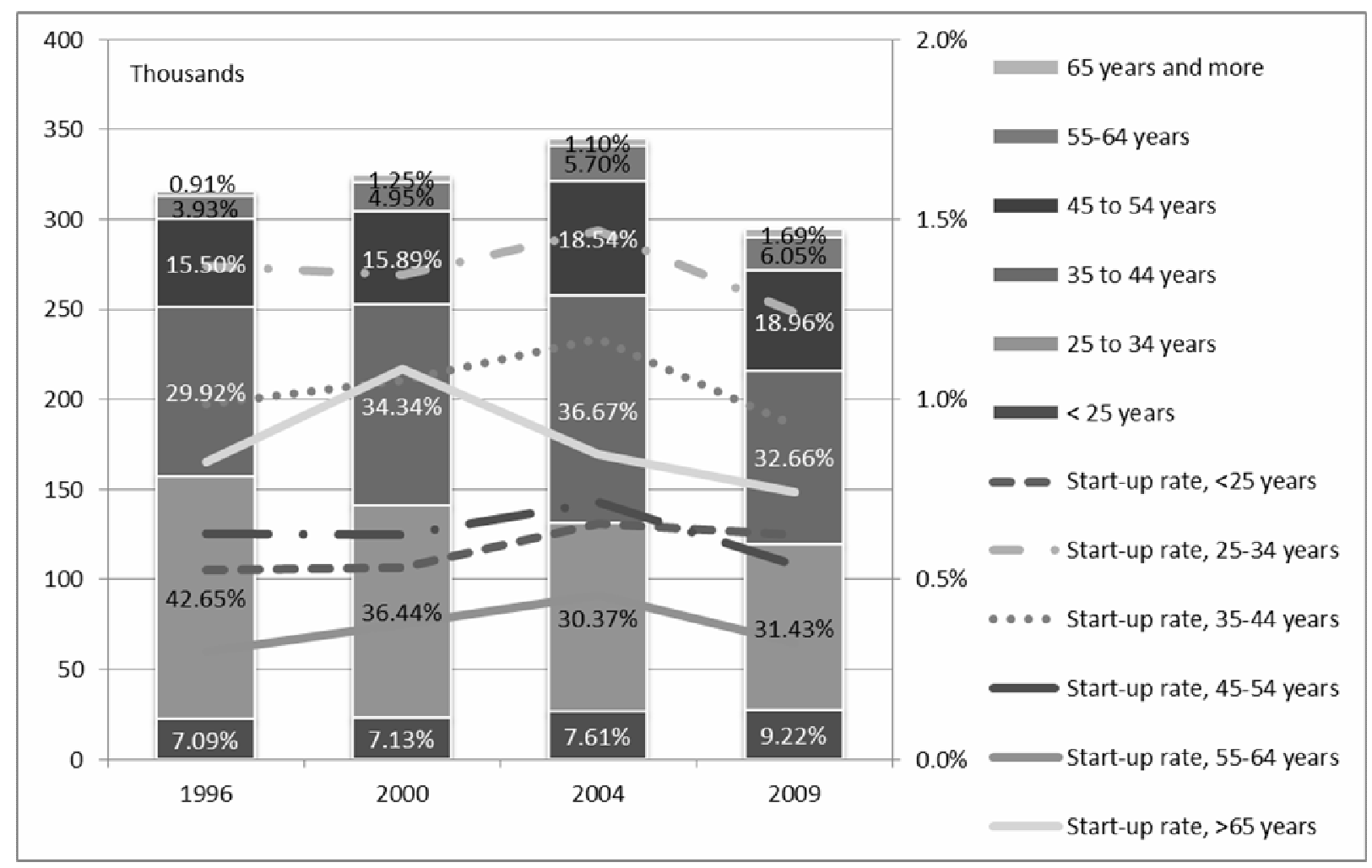

Figure 8: New business founders and age structure, absolute numbers, shares, and cohort-specific start-up rates, 1996-2009

Businesses are most commonly started by persons aged between 25 and 44 years - accounting for around two third of all start-ups (Figure 8 and Table A5). Two more facts are also interesting: among the four years picked for our description, we find the often cited $^{20}$ peak of start-ups by middle aged persons between 35 and 44 years only for 2004. In 1996 and 2000 the share of start-ups was highest for the age cohort between 25 and 34 . In 2009, the shares for the 25 to 34 and the 35 to 44 cohorts were almost the same. Moreover, the share of older business founders increased, while we find a decrease by more than 10 percentage points for the younger business founders who are between 25 and 34 years old making clear that the demographic changes in the population became noticeable.

Several differences in the age structure of business founders as compared to all self-employed individuals can be found in the cohort-specific willingness to set up a new business. First, the start-up rate among the older cohorts is relatively low, for instance, only 0.3 percent of the 55-65 year old people started a business in 2009. Second, the start-up rate in the youngest cohort, when compared to other age

\footnotetext{
${ }^{20}$ See for instance Parker (2009) or Caliendo and Kritikos (2010).
} 
cohorts, remains rather low over time, namely at the level of about 0.6 percent. Thus, unlike the self-employment rate that increases with age-cohorts, the cohort- specific start-up rate is highest among middle aged individuals.

\subsubsection{Gender, marital status and nationality of self-employed and business founders}

A stylized fact is that self-employment is predominantly a male business (see, e.g., Blanchflower, 2000). While this is still true to a certain extent, the share of selfemployed women has continuously become larger - from around 25 percent in 1991 to 31 percent in 2009 (Figure 9) - although both the number of male and female selfemployed persons grew constantly over time in absolute terms. When relating the number of self-employed to the complete working population, it becomes clear that among all working women around 7 percent are self-employed, constituting about half of the corresponding male level.

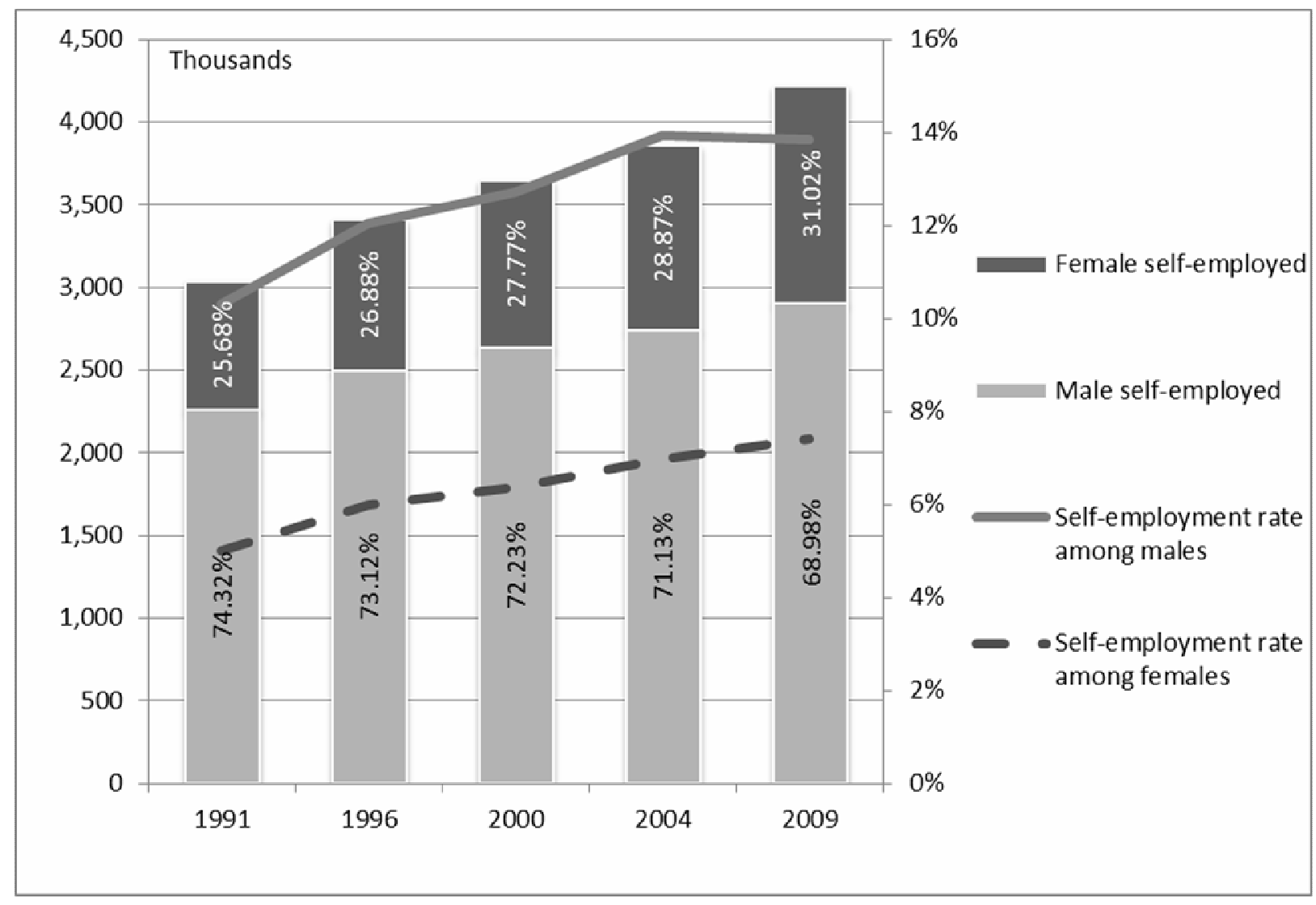

Figure 9: Self-employment and gender, absolute numbers, shares, and selfemployment rates, 1991-2009 


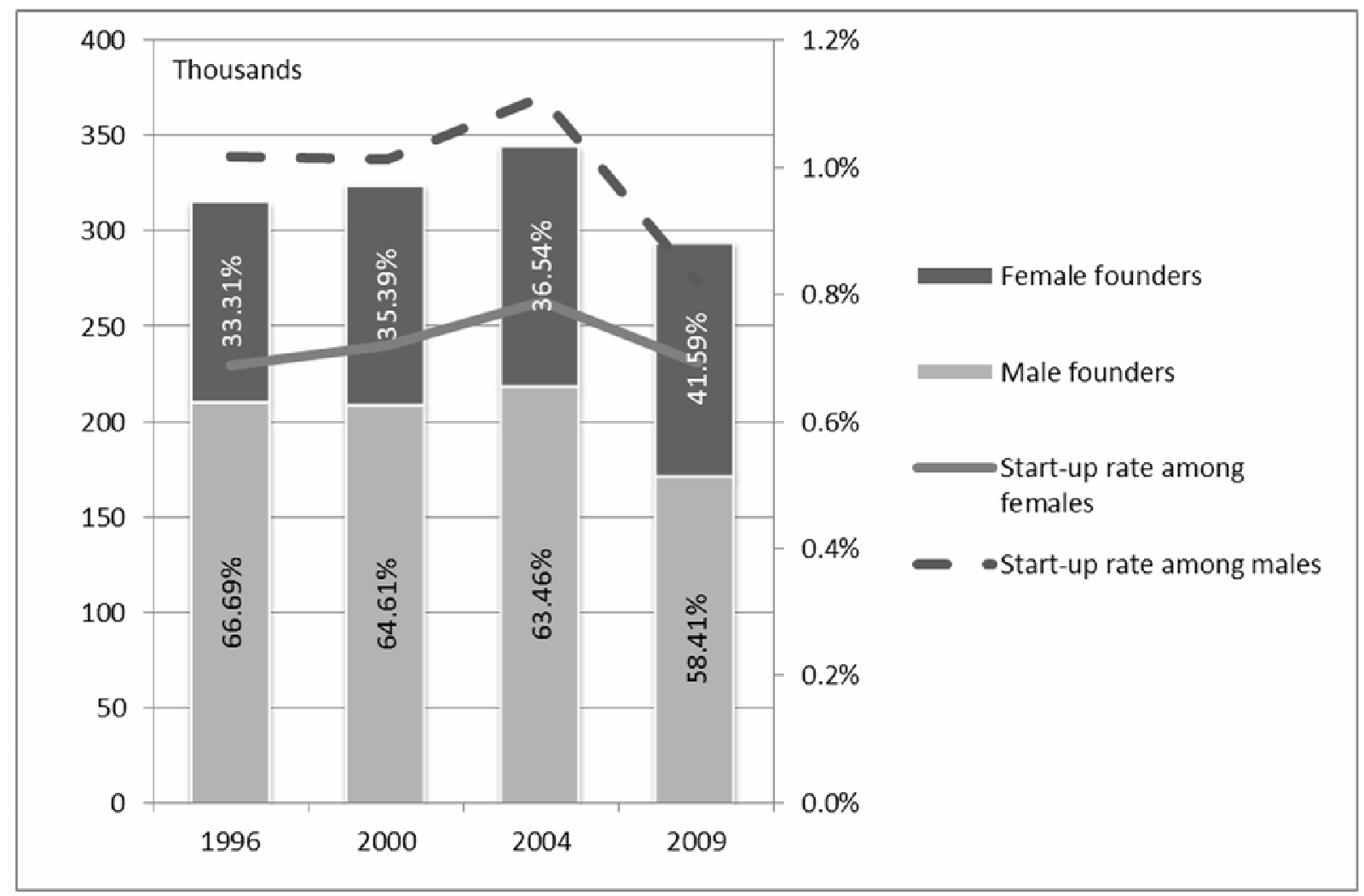

Figure 10: New business founders and gender, absolute numbers, shares, and start-up rates, 1996-2009

Again, the driving force of this change is the fact that the share of female founders increased from 33.3 percent in 1996 to 41.6 percent in 2009 (see Figure 10). However, the share of female start-ups among the female working population is considerably lower and less volatile than among men: the start-up rate among men increased until 2004 when it achieved a level of 1.1 percent and then fell to the level of 0.8 percent in 2009 , which is below the initial rate in 1996 . The female start-up rate, in contrast, constantly remained at 0.7 percent.

With regard to the marital status we find that singles among self-employed became more common over time and accounted for more than 35 percent of all selfemployed in the year 2009. For comparison, this share was below 25 percent in 1991 (see Figure 11). Higher shares of singles among self-employed are not only the result of a prevalent population trend; in fact, the share of singles among selfemployed grew almost 1.2 times faster than the corresponding share among the dependently employed individuals over time. Also this trend can be traced back to the fact that among the business founders the majority is single whose share increased from 43.61 percent in 1996 to 52.5 percent in 2009 (see Figure 12). 


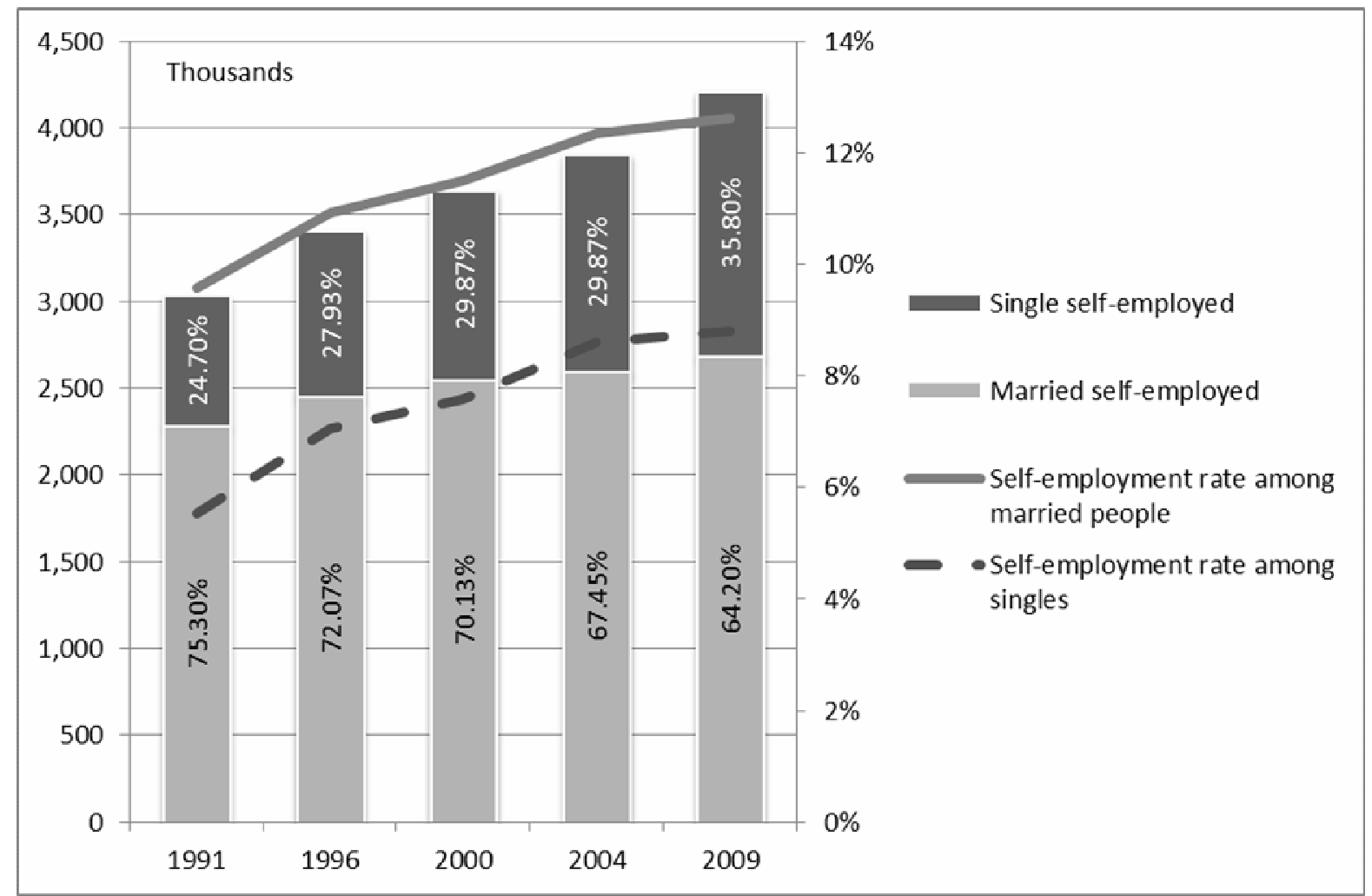

Figure 11: Self-employment and marital status, absolute numbers, shares, and selfemployment rates, 1991-2009

A more recent topic is the development of entrepreneurial activities among migrants. The share of non-Germans among all self-employed people grew continuously from 5.7 percent in 1991 to 9.6 percent in 2009 (see Figure 13). Interestingly, over the observation period, the self-employment rate in the group of non-Germans, which was below the self-employment rate among the German population in 1991, almost doubled within the two decades with exceptionally high shares of self-employed migrants (almost 50 percent) being self-employed in the sector "trading and hospitality". In the year 2009, it reached a value of 12.1 percent among the migrants as compared to 10.7 percent among the German population. This development goes along with the enlargement of the European Union and the consequent increase in labor market mobility, which made it easier for many foreigners to set up a business in Germany. 


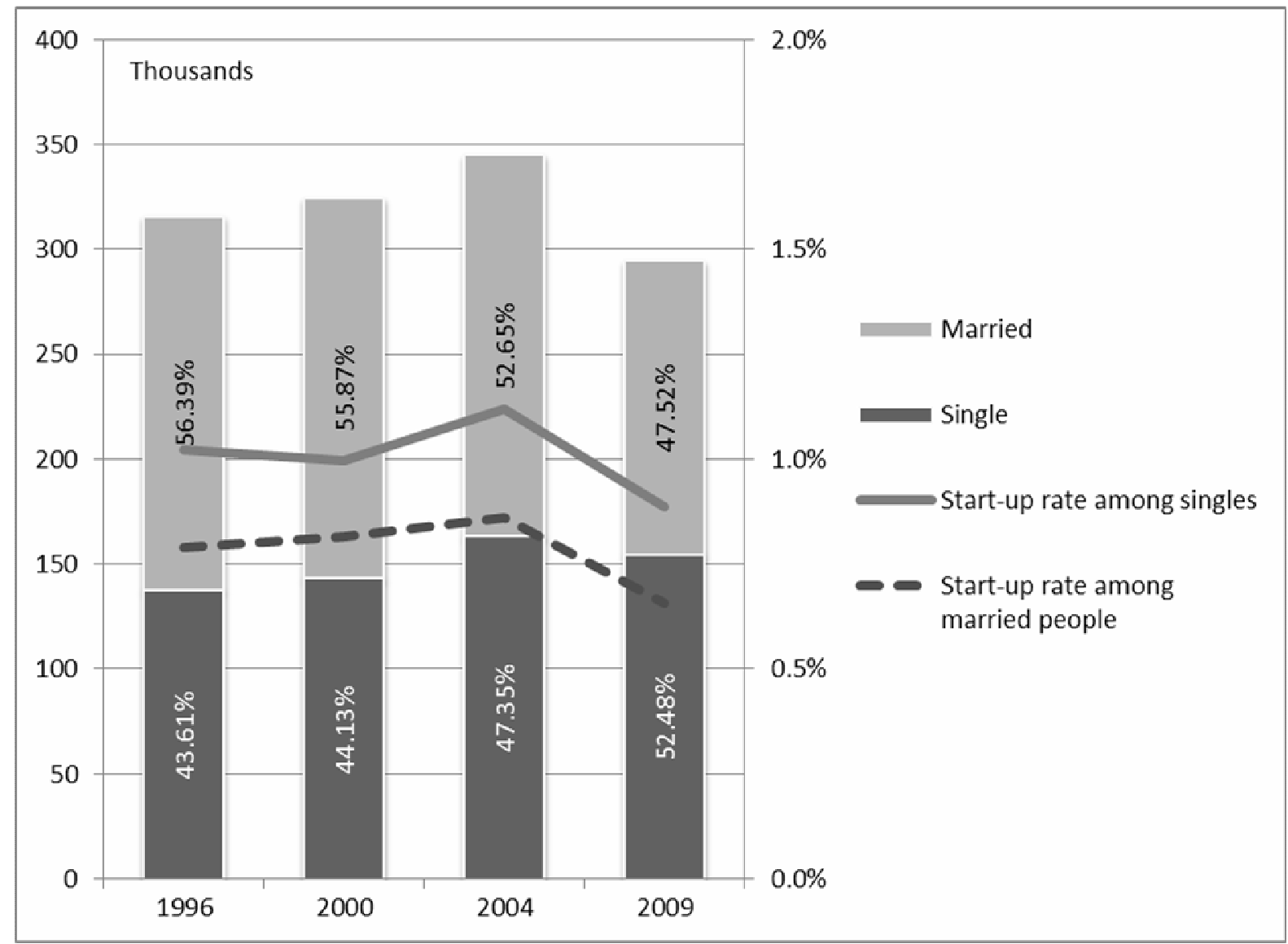

Figure 12: New business founders and marital status, absolute numbers, shares, and start-up rates, 1996-2009

This development among migrants is reflected in their dynamic start-up activities. The rate of business founders among non-Germans exceeded the start-up rate of Germans from the beginning of the observation period (Figure 14). Over the years it grew to 1.5 percent in 2009, while the start-up rate of Germans declined to 0.7 percent. 


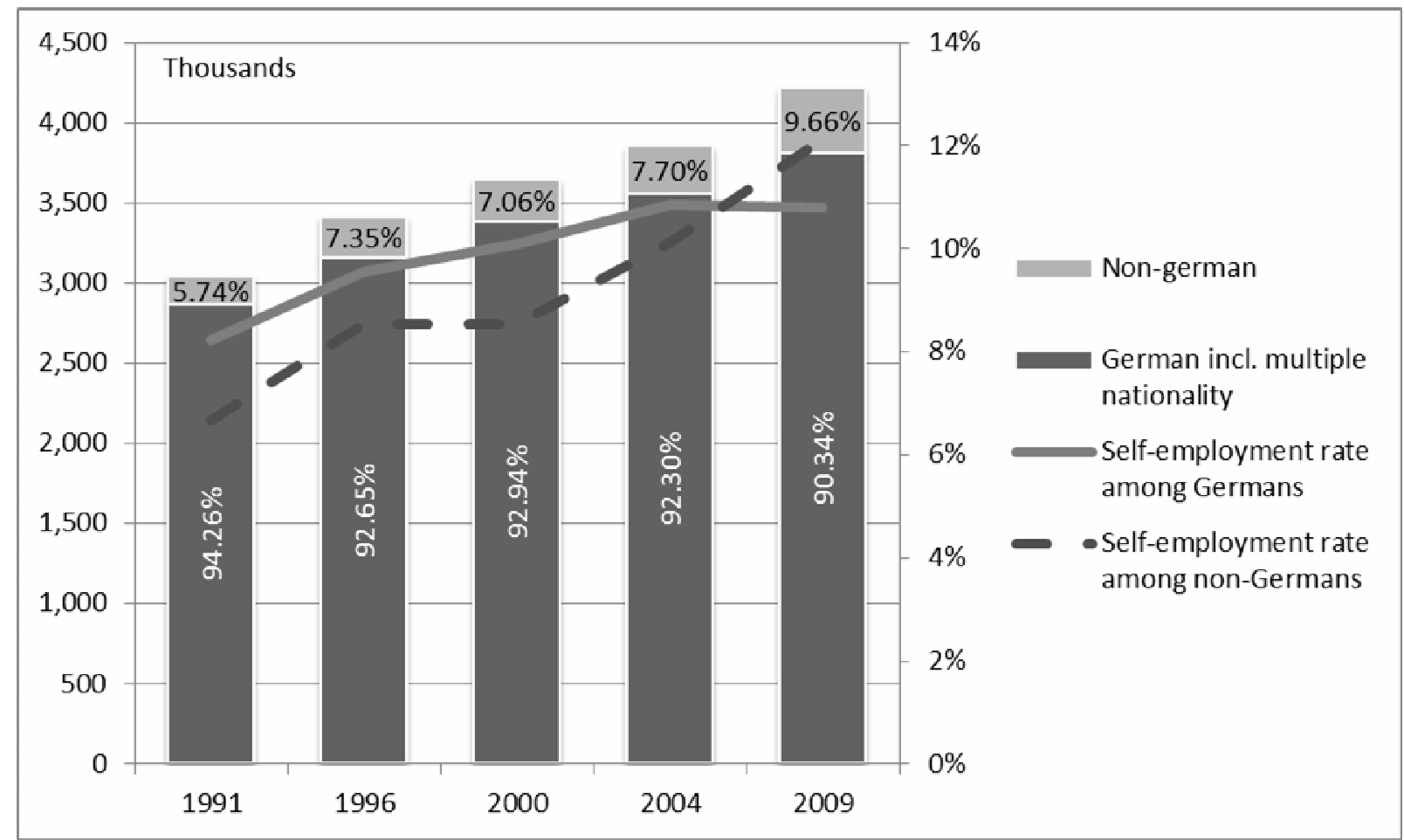

Figure 13: Self-employed and nationality, absolute numbers, shares, and selfemployment rates, 1991-2009

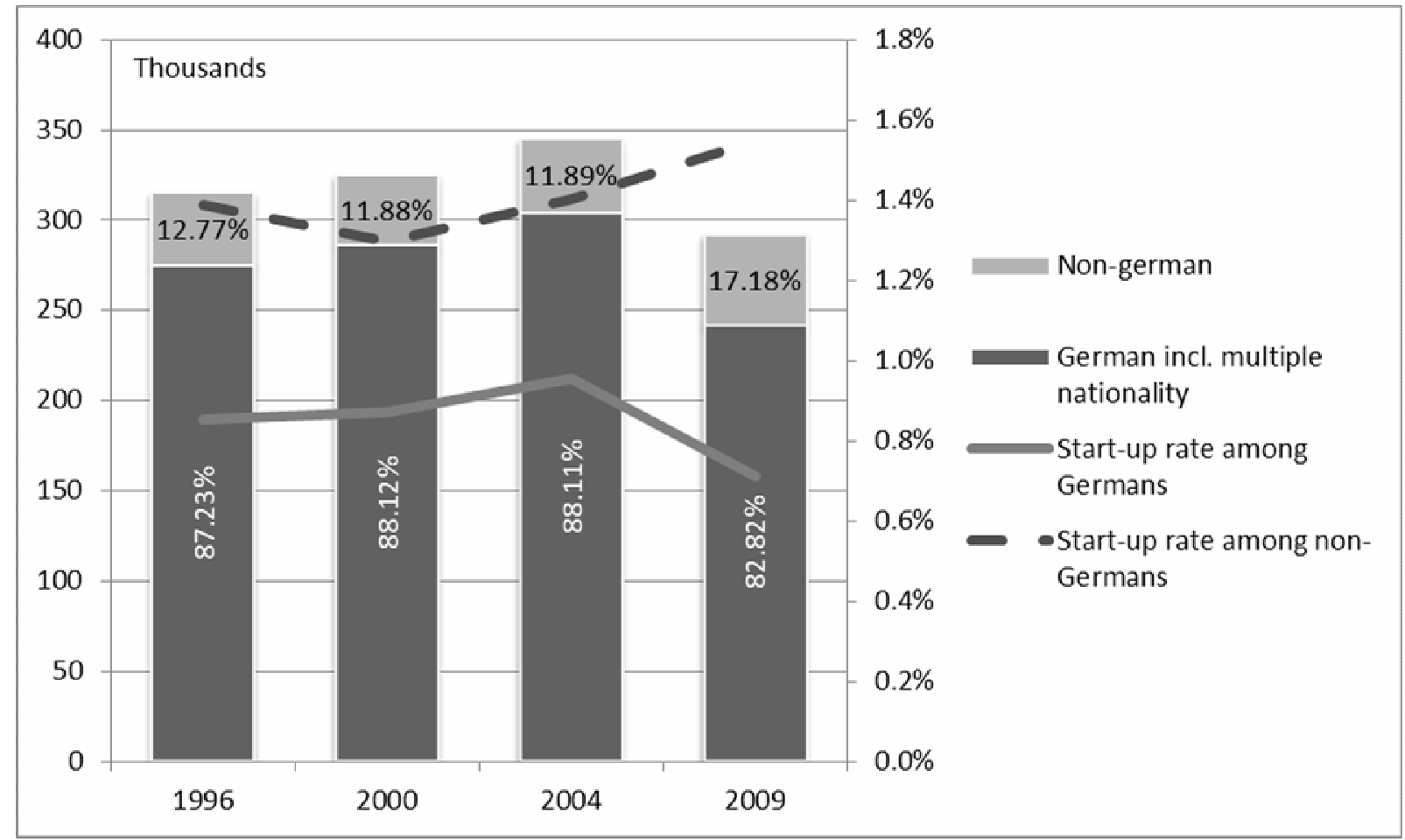

Figure 14: New business founders and nationality, absolute numbers, shares, and start-up rates, 1996-2009 


\subsection{Education and experience of self-employed and of business founders}

Expectations about the influence of educational levels on entrepreneurship are twofold. First, it is often stated that the share of those who have finished tertiary education among business founders and among self-employed is higher than in the total population of employed persons (see Hinz and Jungbauer-Gans, 1999, Caliendo et al., 2009). Second, studies provide empirical evidence that suggests a ushaped relationship between entrepreneurship and educational attainment with relatively high self-employment rates for the highest and the lowest levels of education (see e.g. Poschke, 2008, for the US and Schjerning and Le Maire, 2007, for Denmark).

According to the Micro-Census, self-employed people with a completed vocational education made the largest share of all self-employed in Germany throughout the observation period, followed by those holding a tertiary degree and those who do have neither a tertiary degree nor any further vocational education. ${ }^{21}$ Nevertheless, the largest increase of self-employed was observed among individuals with a tertiary education; they more than doubled over time from 501,000 (18.4 percent of all self-employed) in 1991 to 1.25 million (30 percent) 2009 (Figure 15 and Table A6), while the share of self-employed with vocational education shrank by almost the same amount. It is also remarkable that the self-employment rate in the best educated category grew from 12 percent 1991 to 18 percent in 2005, while the amount of self-employment among the working population in the other two categories grew relatively moderately over time.

It is quite striking that each year around 60 percent of all business founders have a vocational degree and that individuals with a tertiary degree account for about 20 to 25 percent, while only 15 to 20 percent of the business founders have neither a tertiary degree nor any vocational education (Figure 16 and Table A7). The start-up rates of the two lower educational groups, when related to the working population with the same

\footnotetext{
${ }^{21}$ The levels of education are aggregated to three groups for purposes of comparison over time. Particularly, we differentiate between people who hold a vocational degree, tertiary degree, and those who do hold neither a vocational education nor a tertiary degree. The group of those with a vocational degree includes persons who completed semi-skilled training, apprenticeship, vocational school, as well as education to master craftsmen or technician. The group of those with a tertiary degree includes graduates from a university, university of applied sciences ("Fachhochschule"), and those who hold a $\mathrm{PhD}$ degree. One should be aware that information about the highest level of education was first gathered in the Micro-Census in the year 1996. In previous years the Micro Census asked about the most recently achieved level of education.
} 


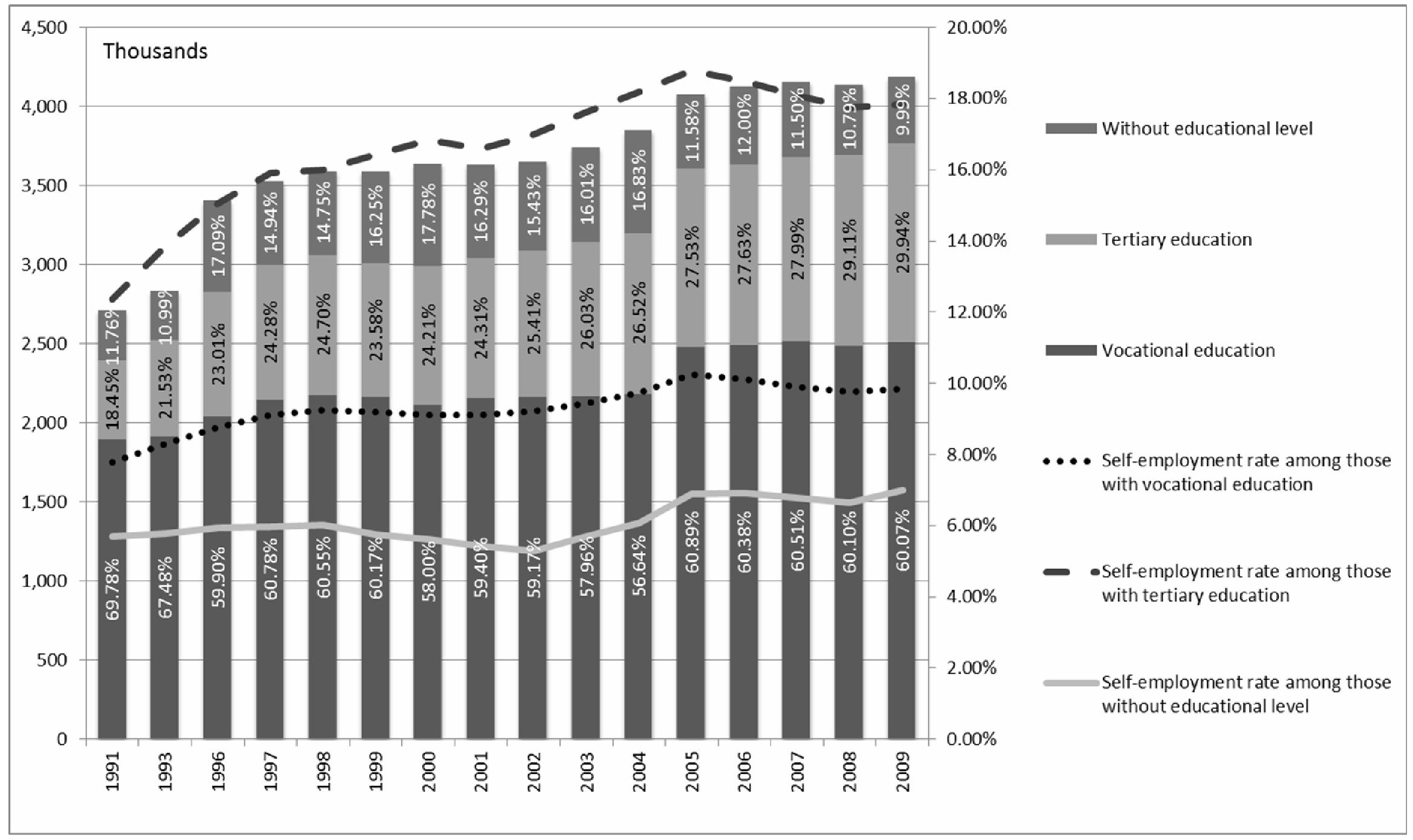

Figure 15: Self-employment and the highest level of education, absolute numbers, shares, and self-employment rates, 1991-2009 


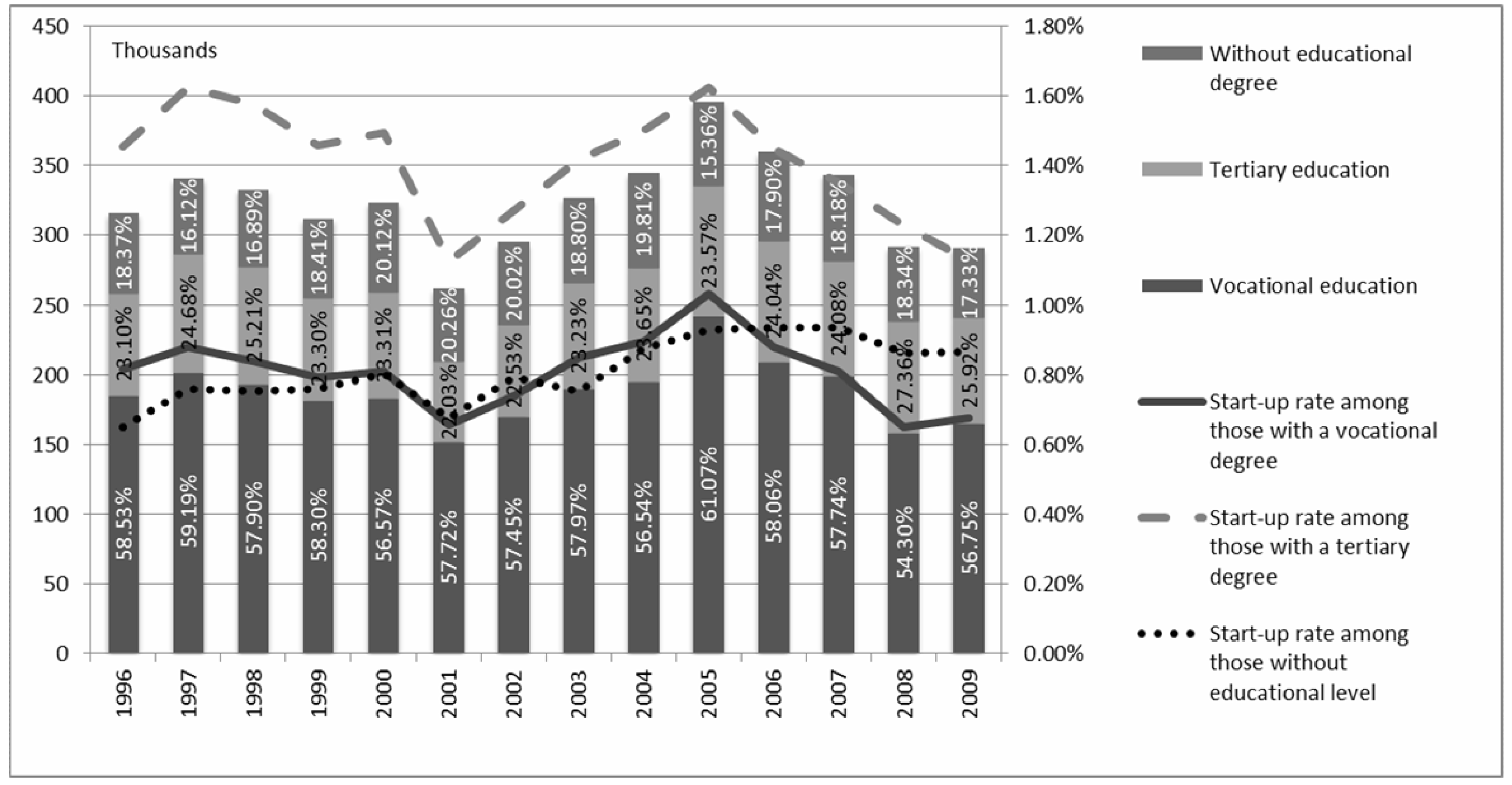

Figure 16: New business founders and the highest level of education, absolute numbers, shares, and start-up rates, 1996-2009 
educational level, are relatively low remaining below 1 percent in all years.

Remarkably, there is a positive trend in the start-up rate for those without a tertiary degree and vocational education: increasing from about 0.6 percent in 1996 to nearly 0.9 percent in 2009. Overall, the start-up rates are much higher among the working population with a tertiary degree and oscillate between 1.2 and 1.6 percentage points.

Table 1: Previous employment status of new business founders; Micro-Census panel, 2001-2004.

\begin{tabular}{|c|c|}
\hline & $\begin{array}{c}\text { Percent } \\
\text { of all } \\
\text { founders }\end{array}$ \\
\hline \multicolumn{2}{|c|}{ Previous occupational status of new business founders } \\
\hline Unemployed & 24.31 \\
\hline Not-employed & 11.4 \\
\hline Self-employed without employees & 11.58 \\
\hline Self-employed with employees & 6.12 \\
\hline Helping in family business & 1.16 \\
\hline Civil cervant & 0.7 \\
\hline Employee & 31.22 \\
\hline (Home-)Worker & 11.92 \\
\hline Commercial apprentice & 0.71 \\
\hline Industrial apprentice & 0.36 \\
\hline Professional soldier & 0.43 \\
\hline Military servants & 0 \\
\hline Civilian servants & 0.09 \\
\hline Total & 100 \\
\hline \multicolumn{2}{|l|}{ School attendance in previous year } \\
\hline Primary or secondary school & 0.55 \\
\hline Vocational training & 3.18 \\
\hline Tertiary education & 4.78 \\
\hline Does not visit school or not reported & 91.49 \\
\hline Total & 100 \\
\hline
\end{tabular}

The German Micro-Census panel data for the years 2001-2004 allow for a more detailed analysis of educational background and previous labor market 
experience of entrepreneurs. ${ }^{22}$ Concerning the previous employment status we find that 31.2 percent of business founders were in dependent employment the year before they set up their businesses and about 12 percent were home-workers. About 24.3 percent were unemployed the year before start-up and 11.4 percent were otherwise non-employed. Most importantly, about 18 percent of the business founders were already self-employed one year before they launched their new venture (Table 1), ${ }^{23}$ which comes closest to the definition of "die-hard-entrepreneurs" (see Burke, et al., 2008). It is also remarkable that only a minority of individuals starts a business directly after finishing their education. We find that only 5 percent of all business founders were in tertiary education and about 3 percent in vocational training during the year prior to establishing their businesses. This could be interpreted in the sense that most of the business founders want to gather some practical experience before venturing into self-employment.

As mentioned before, there is evidence in other countries of a U-shaped relationship between entrepreneurship and educational attainment. We investigate this relationship using the Scientific Use File of the Micro-Census panel data 20012004. Table 2 reports descriptive statistics for educational attainment of business founders and dependently employed individuals (columns 1 - 2). Additionally, it shows shares of entrepreneurs in the population of employed individuals in age between 18 and 65 years old (column 3). The highest start-up rates are observed in cohorts of individuals who hold a tertiary degree, especially those who finished a PhD (1.29 percent), and among master craftsmen.

Results of a probit regression for the panel data in Table 3 does not suggest a curvilinear form of the relationship between formal education and the probability of transition into self-employment. On the contrary, it seems that the probability of becoming self-employed increases monotonously with the educational levels. Moreover, master craftsmen are significantly more likely to become self-employed as

\footnotetext{
${ }^{22}$ The absolute number of business founders in the panel dataset deviates slightly from the original cross-sections of the Micro-Census (Statistisches Bundesamt, 2009). For comparison, the absolute number of new business founders in the cross-section wave 2004 is 345,000 . The same wave of the Micro-Census panel only contains information about 343,000 entrepreneurs. Since the German MicroCensus does not follow individuals after they moved out of the survey district, panel attrition might be a possible explanation for such a deviation.

${ }^{23}$ We do not know whether those individuals gave up previous self-employment or they launched another business recently in addition to an already existing business.
} 
Table 2: Educational attainment of new business founders, shares and rates (\%); Micro-Census panel 2001-2004.

\begin{tabular}{|l|c|c|c|}
\hline \hline & $\begin{array}{c}\text { Self- } \\
\text { employed } \\
(<1 \text { year })\end{array}$ & $\begin{array}{c}\text { Dependently } \\
\text { employed }\end{array}$ & Start-up rate \\
\hline Without educational degree or not reported & 19.99 & 22.85 & 0.72 \\
Semi-skilled training & 1.12 & 1.38 & 0.66 \\
Apprenticeship & 41.16 & 49.93 & 0.67 \\
Vocational school & 3.77 & 3.51 & 0.85 \\
Master craftsmen/Technician & 10.61 & 6.89 & 1.04 \\
Vocational school of the GDR & 1.69 & 1.78 & 0.77 \\
University of Administration & 2 & 2.34 & 0.67 \\
University of Applied Sciences & 9.62 & 5.59 & 1.27 \\
University & 8.47 & 4.99 & 1.22 \\
PhD & 1.59 & 0.75 & 1.29 \\
\hline Total & 100 & 100 & 0.79 \\
\hline \hline
\end{tabular}

Table 3: Educational attainment and propensity to start-up: probit regression for panel data

\begin{tabular}{|lcc|}
\hline \hline Dependent variable: start-up (yes=1, no=0) & Coefficient & Standard error \\
\hline Semi-skilled training & 0.026 & $(0.143)$ \\
Apprenticeship & 0.015 & $(0.045)$ \\
Vocational school & 0.143 & $(0.087)$ \\
Master craftsmen/Technician & $0.232^{\star \star *}$ & $(0.064)$ \\
Vocational school of the GDR & 0.187 & $(0.123)$ \\
University of Administration & -0.012 & $(0.114)$ \\
University of Applied Sciences & $0.326^{* * *}$ & $(0.066)$ \\
University & $0.344^{* * *}$ & $(0.068)$ \\
PhD & $0.387^{* \star *}$ & $(0.132)$ \\
Age & $0.040^{* * *}$ & $(0.010)$ \\
Age, squared & $-0.001^{\star * *}$ & $(0.000)$ \\
Male & $0.145^{* * *}$ & $(0.033)$ \\
Married & $-0.064^{*}$ & $(0.037)$ \\
German & $-0.279^{* * *}$ & $(0.060)$ \\
Constant & $-3.692^{* * *}$ & $(0.221)$ \\
Rho & 0.463 & $(0.032)$ \\
\hline Number of observations & 137596 & \\
Wald Chi ${ }^{2}$ & $160.87^{* * *}$ & \\
Log Likelihood & -6104.38 & \\
\hline \hline
\end{tabular}


compared to those without educational degree. This means that for Germany we have to reject the $u$-shape relationship between educational attainment and entrepreneurship. There is rather a positively linear relationship with a certain kinked curve capturing the special effect of master craftsmen.

\subsection{Income of self-employed and of business founders}

The Micro-Census also provides information on the income situation of German residents as it measures the monthly individual net income. This measure summarizes all possible income sources of an individual and provides income groups rather than the detailed income values. In order to keep the group of business founders rather homogenous with regard to the motivation for a start-up, we follow all individuals of the subgroup of business founders who were employed in 2001 and launched their businesses in 2002. Starting with 2001 data, we were able to analyze the income of business founders in their previous dependent employment. In this group of 135 individuals, 74 percent remained in self-employment over the first three years.

Several studies show that the income distribution of entrepreneurs is different from that of wage employees (see e.g. van Praag and Versloot, 2007, for an overview). Thus, comparing mean levels of income distributions might be misleading. Hamilton (2000) provides evidence for the US that entrepreneurs' income distribution is characterized by lower median values and a higher variation than employees' income distribution.

A first idea about the income distribution of self-employed individuals and dependently employed persons in the Micro-Census data can be revealed in Table 4. We can confirm that about one quarter of all self-employed earn less than 1,100 Euro per month. Remarkably, a much higher share of dependently employed people, namely 35 per cent, earn the corresponding wages. At the same time, about 37 per cent of all self-employed people and only about 17 per cent of all dependently employed persons have a monthly income of more than 2,300 Euro.

The Micro-Census is suitable for the analysis of percentiles of the income distribution for business founders during a 4-year period, as well as all for selfemployed and employees. First of all, comparing the income distribution of business founders in the year before they started their own business, when they were in paid employment, with the income distribution of all wage employees reveals that there are no substantial differences in percentiles of the income. The only difference is that 
Table 4: Distribution of net monthly income in the year 2010 among self-employed and dependently employed persons (shares in \%)

\begin{tabular}{|lcc|}
\hline \hline Income, in Euro & Self-employed & Dependently employed \\
\hline$<1,100$ & 26.78 & 34.04 \\
$1,100<2,300$ & 36.61 & 48.71 \\
$2,300<3,200$ & 14.92 & 10.70 \\
$3,200<4,500$ & 10.11 & 4.60 \\
$4,500<5,500$ & 11.58 & 1.94 \\
\hline Total & 100 & 100 \\
\hline \hline
\end{tabular}

Table 5: Income (in Euro) distribution of business founders, self-employed, and employees

\begin{tabular}{|c|c|c|c|c|c|c|}
\hline \multirow[b]{2}{*}{$\begin{array}{l}\text { Percen- } \\
\text { tile: }\end{array}$} & \multicolumn{4}{|c|}{ Founders* } & \multirow{2}{*}{$\begin{array}{c}\text { Self-employed } \\
2001-2004\end{array}$} & \multirow{2}{*}{$\begin{array}{c}\begin{array}{c}\text { Dependently } \\
\text { employed }\end{array} \\
2001-2004\end{array}$} \\
\hline & 2001 & $\begin{array}{c}2002 \\
\text { (year of start-up) }\end{array}$ & 2003 & 2004 & & \\
\hline 10 & $<1,100$ & $<1,100$ & $<1,100$ & $<1,100$ & $<1,100$ & $<1,100$ \\
\hline 20 & $<1,100$ & $<1,100$ & $<1,100$ & $<1,100$ & $<1,100$ & $<1,100$ \\
\hline 30 & $<1,100$ & $<1,100$ & $<1,100$ & $1,100-2,300$ & $1,100-2,300$ & $<1,100$ \\
\hline 40 & $<1,100$ & $1,100-2,300$ & $1,100-2,300$ & $1,100-2,300$ & $1,100-2,300$ & $1,100-2,300$ \\
\hline 50 & $1,100-2,300$ & $1,100-2,300$ & $1,100-2,300$ & $1,100-2,300$ & $1,100-2,300$ & $1,100-2,300$ \\
\hline 60 & $1,100-2,300$ & $1,100-2,300$ & $1,100-2,300$ & $1,100-2,300$ & $1,100-2,300$ & $1,100-2,300$ \\
\hline 70 & $1,100-2,300$ & $1,100-2,300$ & $2,300-3,200$ & $2,300-3,200$ & $2,300-3,200$ & $1,100-2,300$ \\
\hline 80 & $1,100-2,300$ & $2,300-3,200$ & $3,200-4,500$ & $3,200-4,500$ & $3,200-4,500$ & $1,100-2,300$ \\
\hline 90 & $2,300-3,200$ & $3,200-4,500$ & $4,500-5,500$ & $4,500-5,500$ & $4,500-5,500$ & $2,300-3,200$ \\
\hline
\end{tabular}

* Only founders who were in dependent employment in 2001.

business founders in the $40^{\text {th }}$ percentile of the income distribution earned less than employees in dependent employment (see Table 5). Thus, start-up activities can be observed in all income groups and it seems that there is no bias toward particularly low incomes in the start-up group. 
In the year of start-up (2002), the income of the $80^{\text {th }}$ and the $90^{\text {th }}$ percentiles of entrepreneurs were larger than that of dependently employed persons. In the subsequent years the income distribution of business founders already exceeded that of employees in lower percentiles (in the $70^{\text {th }}$ percentile in 2003 and in the $30^{\text {th }}$ percentile in 2004). When comparing business founders and all self-employed, it is striking that the income distribution of founders is rather similar to that of all selfemployed after only three years. Last, but not least, when comparing the incomes of the dependently employed with self-employed persons (and with entrepreneurs in the third year of their venture) it is obvious that there is a much lower share of selfemployed earning less than 1,100 Euros. At the same time there is a much larger share of self-employed persons earning more than 2,300 Euro per month than among the dependently employed.

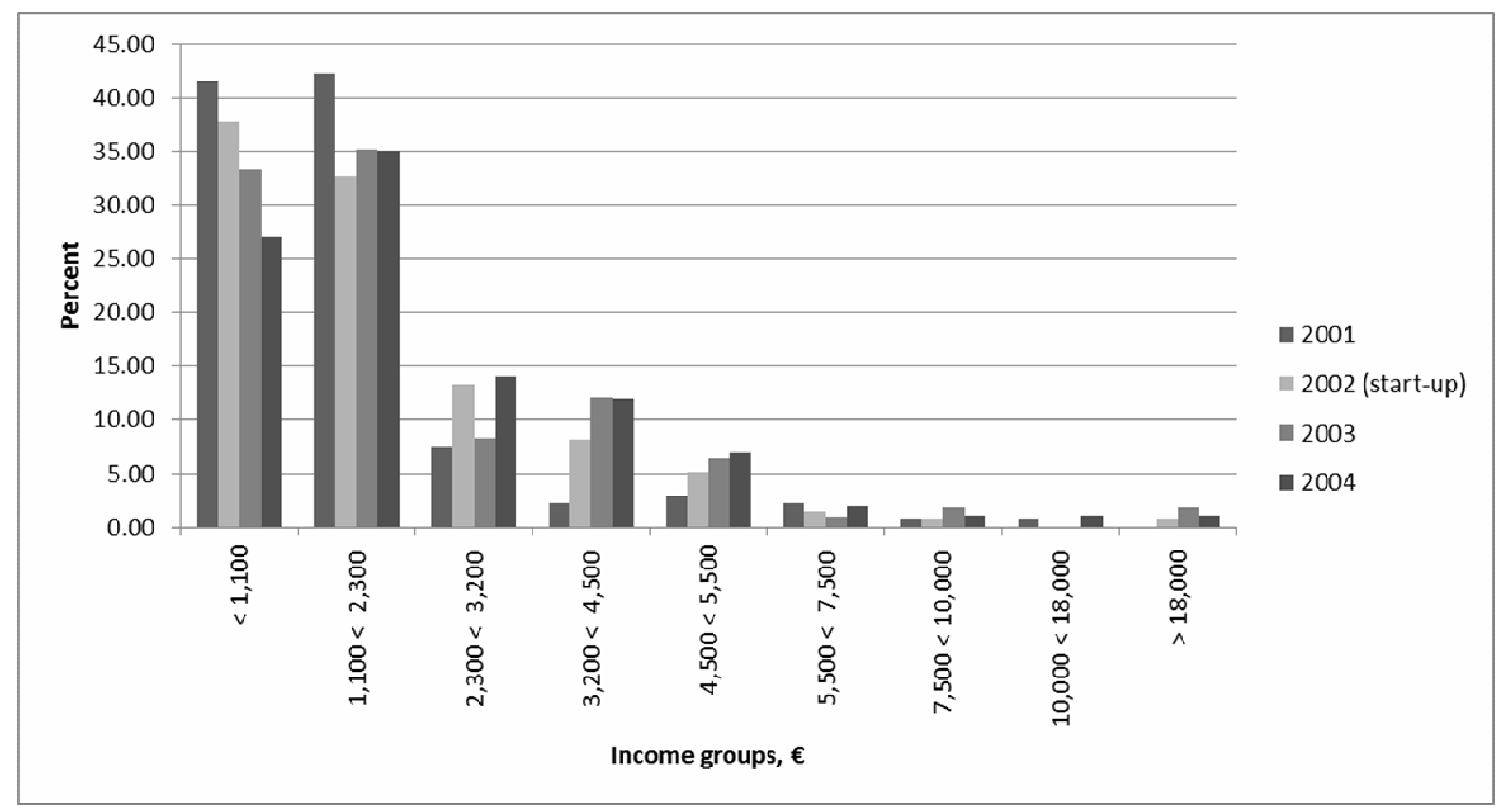

Figure 17: Income of new business founders before and after start-up

Further information is revealed in Figure 17 and Table 6 where we show the income development of business founders beginning in the year before the start-up and the first three years after the start-up. Having decided to become an entrepreneur, we find that this decision improves, on average, a person's financial situation. Overall, 38 percent of entrepreneurs have improved their financial situation within three years after start-up, as compared to the year before the start-up; 45 
Table 6: Distribution (shares in \%) and development of individual income before and after start-up; Micro-Census panel $2001-2004$.

\begin{tabular}{|l|c|c|c|c|c|c|c|}
\hline \hline & & \multirow{2}{*}{$\begin{array}{c}2002 \\
\text { Income (Euro) }\end{array}$} & 2001 & $\begin{array}{c}|c| \\
\text { (year of } \\
\text { start-up) }\end{array}$ & 2003 & 2004 & \multicolumn{3}{|c|}{ Individual income in 2004 versus } \\
\cline { 6 - 8 } & & & & decreased & $\begin{array}{c}\text { remained } \\
\text { unchanged }\end{array}$ & increased \\
\hline$<1,100$ & 41.48 & 37.78 & 33.33 & 27.00 & 0 & 48.65 & 51.35 \\
$1,100<2,300$ & 42.22 & 32.59 & 35.19 & 35.00 & 19.05 & 47.62 & 33.33 \\
$2,300<3,200$ & 7.41 & 13.33 & 8.33 & 14.00 & 55.56 & 33.33 & 11.11 \\
$3,200<4,500$ & 2.22 & 8.15 & 12.04 & 12.00 & 0 & 33.33 & 66.67 \\
$4,500<5,500$ & 2.96 & 5.19 & 6.48 & 7.00 & 25 & 50 & 25 \\
$5,500<7,500$ & 2.22 & 1.48 & 0.93 & 2.00 & 66.67 & 33.33 & 0 \\
$7,500<10,000$ & 0.74 & 0.74 & 1.85 & 1.00 & 100 & 0 & 0 \\
$10,000<18,000$ & 0.74 & 0.00 & 0.00 & 1.00 & 0 & 0 & 100 \\
$>18,000$ & 0.00 & 0.74 & 1.85 & 1.00 & - & - & - \\
Exit rate & - & - & 20.00 & 7.41 & - & - & - \\
Total & 100 & 100 & 100 & 100 & 17.00 & 45.00 & 38.00 \\
\hline \hline
\end{tabular}

percent remained in the same income group and 17 percent downgraded to a lower income group. Remarkably, the share of entrepreneurs in the lowest income group, "less than 1,100 Euro," decreased from 41.5 percent in 2001 to 27 percent year 2004. The same holds true for the second lowest income group, "1,100 - 2,300 Euro," where the share decreased from 42 percent in 2001 to 35 percent in 2004. Accordingly, we observe an increase in the percentage of individuals in the next three income groups between 2,300 and 5,500 Euro. Even in the highest income groups the share of entrepreneurs increased to certain extent. Overall these results clearly show that for most self-employed individuals the change from paid to selfemployment increases the income - this holds particularly true for the share with very low incomes.

This observation leads also to the question of what happened to the individuals who gave up during the first years of self-employment. The percentage of entrepreneurs who gave up in the first year after the start-up (2003) was 20 percent. In the second year (2004) another 7.4 percent of entrepreneurs quitted and did not try to start another business during the observation period. A more precise look (Table 7) at the income development of the quitters reveals that the majority of those persons (about 54 percent) initially came from the low-income group of "less than 
Table 7: Shares (\%) of quitters from self-employment in different income groups 2001-2004

\begin{tabular}{|l|c|c|c|c|}
\hline \hline Income groups (Euro) & 2001 & $\begin{array}{c}2002 \\
\text { (start-up) }\end{array}$ & 2003 & 2004 \\
\hline$<1,100$ & 54.29 & 57.14 & 60 & 60 \\
$1,100<2,300$ & 42.86 & 31.43 & 34.29 & 31.43 \\
$2,300<3,200$ & 2.86 & 5.71 & 2.86 & 5.71 \\
$3,200<4,500$ & - & 5.71 & 2.86 & 2.86 \\
\hline Total & 100 & 100 & 100 & 100 \\
Number of observations & 35 & 35 & 35 & 35 \\
\hline \hline
\end{tabular}

1,100 Euro," with 60 percent of those who gave up, also ending up with low incomes three years after start-up. These persons might have stopped their self-employment experience because of income or liquidity problems. Nevertheless, included in the group of individuals who exited self-employment are some who were able to increase their income; they might have given up self-employment because of an attractive job offer.

\section{Determinants of self-employment in Germany}

Last, but not least, we analyze the determinants of the self-employment activities at the beginning, the year 1991, and at the end, the year 2009, of the observation period and conduct this analysis separately for East and West Germany, since the development of self-employment might have proceeded differently due to the historical experiences of people living in these two parts of Germany. The evidence from the descriptive statistics provided in previous sections suggests that the selfemployment activities increased in the last 18 years in East Germany, among females, single persons and foreigners. Furthermore, the average age of selfemployed individuals increased during the period under study. Moreover, the share of highly educated persons among self-employed increased substantially and there is a higher share of self-employed individuals in 2009 as compared to 1991. Hence, we consider the following indicators as determinants of self-employment: age, gender, marital status, nationality, geographical location (East Germany), the service sector, and the level of education. 
Table 8: Determinants of self-employment - Whole of Germany (logit analyses)

\begin{tabular}{|c|c|c|c|c|}
\hline & \multicolumn{2}{|c|}{1991} & \multicolumn{2}{|c|}{2009} \\
\hline & Coefficient & $\begin{array}{l}\text { Marginal fixed } \\
\text { effect }\end{array}$ & Coefficient & $\begin{array}{c}\text { Marginal } \\
\text { fixed effect }\end{array}$ \\
\hline \multirow[t]{2}{*}{ Age } & $0.045^{\star \star *}$ & $0.003^{* \star *}$ & $0.081^{* * *}$ & $0.006^{* * *}$ \\
\hline & $(0.004)$ & $(0.0002)$ & $(0.003)$ & $(0.00026)$ \\
\hline \multirow[t]{2}{*}{ Age, squared } & -0.0001 & $-0.00001^{* * *}$ & $-0.0004^{* * *}$ & $-0.00004^{* * *}$ \\
\hline & $(0.00004)$ & $(0.000)$ & $(0.00004)$ & $(0.000)$ \\
\hline \multirow[t]{2}{*}{ East } & $-0.607^{\star \star *}$ & $-0.032^{\star * *}$ & $0.030^{* *}$ & $0.002^{* *}$ \\
\hline & $(0.018)$ & $(0.0008)$ & $(0.015)$ & $(0.0012)$ \\
\hline \multirow[t]{2}{*}{ Married } & $0.088^{* * *}$ & $0.005^{\star * *}$ & $-0.024^{*}$ & $-0.002^{*}$ \\
\hline & $(0.018)$ & $(0.001)$ & $(0.013)$ & $(0.001)$ \\
\hline \multirow[t]{2}{*}{ Female } & $-0.768^{\star \star \star}$ & $-0.044^{\star \star *}$ & $-0.873^{\star \star *}$ & $-.069^{* * *}$ \\
\hline & $(0.016)$ & $(0.0008)$ & $(0.013)$ & $(0.001)$ \\
\hline \multirow{2}{*}{$\begin{array}{l}\text { German } \\
\text { nationality }\end{array}$} & $0.156^{\star \star \star}$ & 0.008 & $-0.253^{\star * *}$ & $-.022^{\star \star \star}$ \\
\hline & $(0.034)$ & $(0.002)$ & $(0.024)$ & $(0.002)$ \\
\hline \multirow{2}{*}{$\begin{array}{l}\text { Service sector } \\
\text { employment }\end{array}$} & $0.465^{\star \star \star}$ & $0.027^{\star \star *}$ & $0.851^{* * *}$ & $0.064^{* \star *}$ \\
\hline & $(0.015)$ & $(0.0008)$ & $(0.013)$ & $(0.001)$ \\
\hline $\begin{array}{l}\text { Vocational } \\
\text { training }\end{array}$ & $\begin{array}{c}0.297^{\star * *} \\
(0.022)\end{array}$ & $\begin{array}{l}0.016^{* * *} \\
(0.001)\end{array}$ & $\begin{array}{c}0.319^{* * *} \\
(0.021)\end{array}$ & $\begin{array}{c}0.024^{* * *} \\
(0.002)\end{array}$ \\
\hline $\begin{array}{l}\text { Tertiary } \\
\text { education }\end{array}$ & $\begin{array}{c}0.546 \\
(0.027)\end{array}$ & $\begin{array}{l}0.039^{* * *} \\
(0.002)\end{array}$ & $\begin{array}{c}0.851^{* * *} \\
(0.023)\end{array}$ & $\begin{array}{l}0.085^{\star * *} \\
(0.003)\end{array}$ \\
\hline \multirow[t]{2}{*}{ Intercept } & $-4.702^{* * *}$ & & $-5.117^{* * *}$ & \\
\hline & $(0.079)$ & & $(0.072)$ & \\
\hline Pseudo R2 & 0.0774 & & 0.0848 & \\
\hline Log Likelihood & -79262.01 & & -100336.99 & \\
\hline Wald Chi2 & $13592.3^{* \star *}$ & & $17916^{* \star *}$ & \\
\hline $\begin{array}{l}\text { Number of } \\
\text { observations }\end{array}$ & 306204 & & 316686 & \\
\hline
\end{tabular}

We conduct a logit regression using the employment status as dependent variable. Table 8 presents the results for the full sample, i.e. the whole of Germany. We find that all considered variables have a significant influence on the employment status with the age variable showing the expected inverse u-shaped relationship on the probability of being self-employed in a more pronounced way in 2009 than in 1991. It is interesting, though, that some independent variables contribute to the probability of being self-employed with different signs in 1991 and 2009. For instance, while being a resident of East Germany had a significantly negative effect 
in 1991, it became significantly positive by 2009. Moreover, while married people were significantly more likely to be self-employed in 1991, the effect of being married was significantly negative in 2009. And in 2009 Germans were significantly less likely to be self-employed than foreigners, while this effect was positive in 1991 (though the marginal effect did not prove to be significant for this year). Finally, the effect of having a tertiary degree on the probability of self-employment was much larger in 2009 as compared to 1991.

When comparing the determinants of self-employment in East and West Germany separately (Tables A8 and A9), several differences between the two parts of the country are noticeable. First, the effect of being married was significantly positive in West Germany in 1991 but not in East Germany. However, it was significantly negative in 2009 for in East Germany. Overall, the impacts of some of the determinants of self-employment (location in East Germany, marital status, nationality) have changed over time. Some determinants of self-employment (marital status, nationality) were different in East Germany than in West Germany. However, the determinants of self-employment in both parts of the country converged during the observation period and have become rather comparable in 2009.

Thus, indeed the observed variables described in the descriptive part of the paper significantly influenced the probability of being self-employed. It is quite remarkable in this context that the two variables 'service sector' and 'tertiary education' had the highest marginal effects on this probability and that their influence became much stronger over time.

\section{Conclusions}

Based on data from the German Micro Census, a highly representative yearly survey of German households, we analyze the development and determinants of selfemployment and of the start-up activities in Germany. The data reveal a number of interesting facts. First, we observe a unique expansion of the number of selfemployed in Germany. Seemingly obvious reasons such as a particular increase of self-employment in East Germany (the former communist part of the country) fall short of explaining the development as the share of self-employed persons also increased in West Germany between 1991 and 2009. Nevertheless it must be emphasized that at least in the field of the self-employment share, East Germany has successfully caught-up: start-up activities in East Germany exceeded those in WestGermany over the complete observation period. 
At the same time the service sector has become dominant, with every second self-employed individual working in this sector and more than half of all business founders starting in services. The share of female self-employed grew to a certain extent, with the female start-up rate increasing from 33 to over 40 percent between 1996 and 2009. It is also interesting that the start-up rate among singles and nonGermans grew above the average start-up rate for the full sample. Moreover, middle aged individuals are the dominant drivers of self-employment with the highest share of self-employed between 45 and 54 and the highest start-up rates amongst those between 35 and 44 . Another striking result is the influence of education on selfemployment, individuals with a tertiary education more than doubled in the observation period and their start-up rate is by far higher than that for those with differing educational levels. Most remarkably, we are not able to confirm a u-shaped relationship between the education level and the cohort-specific start-up activities. In Germany this relationship is strictly positive.

We also tested with a logit analysis the influence of these parameters on the probability of being self-employed and can confirm that there is a positive relationship between a) East-Germans, b) singles, c) tertiary educated d) Non-Germans and the probability of being self-employed. Also the positive relationship between the service sector and self-employment as well as a u-shaped relationship between age and selfemployment are confirmed. With respect to gender, the negative relationship between females and the probability of being self-employed remained despite the increase in the female start-up rate.

Moreover, it is remarkable where the self-employed are coming from in terms of working experience a year before they started. As expected, the greatest share of business founders were regularly employed during the previous year; however almost 20 percent were starting second firms: these individuals were already selfemployed during the previous year.

The last crucial insight of this analysis is concerned with the income of selfemployed and of business founders during the first three years of their selfemployment activity. When comparing income distributions of self-employed with employees, we observe that a much smaller share of self-employed earn less than 1,100 Euros per month than dependently employed persons. Moreover, we also observe that the majority of the start-ups (when compared to their previous employment situation) earn, during their third year of self-employment, either at least the same or a higher income. Only one in six earn less during the third year after start-up. 
In this context, one longstanding issue of contention in Germany is that a large share of individuals are losing ground as they only earn small incomes. A 2011 study by IfM Bonn found that 26.5 percent of all self-employed earn less 1,100 Euros per month (see May-Strobl, et al., 2011) and criticize that these persons chose the wrong employment status. Our data confirm this share of persons earning less than 1,100 Euros per month. However, our analysis allows for a more differentiated analysis. We found that the transition into self-employment substantially increased the probability of earning more than in dependent employment. Our observations make clear that the low income situation has other underlying reasons, like the choice of the sector or the educational level.

Our analysis also allows for some first conclusions that are relevant for policy advice. First, we mentioned in the introduction the changing policy direction with respect to start-up schemes. The positive income development of entrepreneurs together with the affirmative influence of self-employment on the dynamics of the whole economy rather lead to the conclusion that it pays to have extensive start-up programs supporting the transition from unemployment to self-employment. Second, we observe an increasing share of solo-entrepreneurs. This development makes clear that investments need to be done to increase the quality of the ventures created by these entrepreneurs. Support schemes like offers for coaching might be suited for providing the necessary personal backing to solo-entrepreneurs who are considering hiring individuals. In Germany a federally supported coaching scheme was started in 2007 and it is an open research question whether this scheme will be helpful in successfully increasing the number of self-employed with employees in their company. Third, the high share of self-employed with tertiary degree makes clear how important it is for the German economy to maintain or even better to increase the share of well-educated individuals in the country. This holds true for other parts of employment but the high share of well-educated individuals among the self-employed reinforces the argument for higher education. 


\section{References}

Almus, Matthias, Dirk Engel and Susanne Prantl (2000): the ZEW Foundation Panels and the Mannheim Enterprise Panel (MUP) of the Centre of European Research (ZEW). Journal of Applied Social Science Studies, 120, 301-308.

Audretsch, David B. (2007): The Entrepreneurial Society, Oxford: Oxford University Press.

Blanchflower, David G. (2000): Self-employment in OECD countries. Labour Economics, 7, 471-505.

Boegenhold, Dieter and Uwe Fachinger (2007): Renaissance of Entrepreneurship? Some remarks and empirical evidence for Germany. ZeS-Arbeitspapier No. 2/2007.

Brixy, Udo, et al. (2009): Global Entrepreneurship Monitor: Länderbericht Deutschland 2008. Hannover and Nuremberg.

Burke, Andrew, Felix FitzRoy and Michael A. Nolan (2008): What Makes a Die-Hard Entrepreneur? Beyond the 'Employee or Entrepreneur' Dichotomy, Small Business Economics, 31, 93-115.

Caliendo, Marco, Frank Fossen, and Alexander Kritikos (2009). Risk attitudes of nascent entrepreneurs: New evidence from an experimentally-validated survey. Small Business Economics 32, 153-167.

Caliendo, Marco and Alexander Kritikos (2009): Die reformierte Gründungsförderung für Arbeitslose - Chancen und Risiken, Perspektiven für Wirtschaftspolitik, 10, 189-213.

Caliendo, Marco and Alexander Kritikos (2010): Start-ups by the Unemployed: Characteristics, Survival and Direct Employment Effects, Small Business Economics, 35, 71-92.

Caliendo, Marco and Steffen Künn (2011): Start-Up Subsidies for the Unemployed: Long-Term Evidence and Effect Heterogeneity, Journal of Public Economics, 95, 311-331.

Clemens, R. and G. Kayser (2001): Existenzgründungsstatistik Unternehmensgründungsstatistik, IfM-Materialien Nr. 149, Bonn.

Davidsson, Per (2006): Nascent Entrepreneurship, Foundations and Trends in Entrepreneurship, 2, 1-85.

Fritsch, Michael, Reinhold Grotz, Udo Brixy, Michael Niese and Anne Otto (2002): Die statistische Erfassung von Gründungen in Deutschland - ein Vergleich von Beschäftigtenstatistik, Gewerbeanzeigenstatistik und den Mannheimer Gründungspanels. Allgemeines Statistisches Archiv, 86, 87-96.

Fritsch, Michael (2011): The effect of new business formation on regional development-Empirical evidence, interpretation, and avenues for further research, in: Michael Fritsch (ed.): Handbook of Research on Entrepreneurship and Regional Development, Cheltenham: Edward Elgar, 58106. 
Geroski, Paul (1995): What do we know about entry? International Journal of Industrial Organization,13, 421-440.

Günterberg, Brigitte (2009): Berechnungsmethode der Gründungs- und Liquidationsstatistik des IfM Bonn. Bonn 2009.

Hamilton, Barton H. (2000): Does Entrepreneurship Pay? An Empirical Analysis of the Returns to Self-Employment. Journal of Political Economy, 108, 604-631.

Hinz, T., \& Jungbauer-Gans, M. (1999). Starting a business after unemployment: Characteristics and chances of success. Entrepreneurship and Regional Development 11, 317-333.

Institut für Mittelstandsforschung (2004): Gründungen und Liquidationen im Jahr 2003, Bonn.

Kawka, R. (2007): Regional Disparities in the GDR: Do They Still Matter? in: Lentz, S. (Ed.), German Annual of Spatial Research and Policy: Restructuring Eastern Germany, Springer: Berlin, 111-122.

Kreditanstalt für Wiederaufbau (KfW) (2005): KfW-Gründungsmonitor 2005. Jährliche Analyse von Struktur und Dynamik des Gründungsgeschehens in Deutschland, Frankfurt a.M.: Kreditanstalt für Wiederaufbau.

Kreditanstalt für Wiederaufbau (KfW) (2009) KfW-Gründungsmonitor 2009, Frankfurt am Main: Kreditanstalt für Wiederaufbau.

Kritikos, Alexander (2011): Gründungszuschuss: Ein erfolgreiches Instrument steht zur Disposition, DIW-Wochenbericht 45.

May-Strobl, E.; Pahnke, A.; Schneck, S.; Wolter, H.-J. (2011): Selbstständige in der Grundsicherung, Institut für Mittelstandsforschung (IfM), Bonn, Working Paper No. 02.

Oberlander, Willi (2004): Freie Berufe: positive Zahlen, schwindende Attraktivität, Informationen des IFB Nürnberg.

Parker, Simon (2009): The Economics of Entrepreneurship, Cambridge: Cambridge University Press.

Parker, Simon and Yacine Belghitar (2006): What happens to Nascent Entrepreneurs? An Econometric Analysis of PSED, Small Business Economics, 27, 81-101.

Piorkowsky, M.-B. (2008): Existenzgründungen im Kontext der Arbeits- und Lebensverhältnisse in Deutschland - Eine Strukturanalyse von Mikrozensusergebnissen. Bonn.

Poschke, Markus (2008): Who Becomes an Entrepreneur? Labor Market Prospects and Occupational Choice. IZA Discussion Paper No. 3816.

Reynolds, Paul D. (2005): Global Entrepreneurship Monitor: Data Collection Design and Implementation 1998-2003, Small Business Economics, 24, 205-231.

Reynolds, Paul D. (2007): Entrepreneurship in the United States - The Future is Now, New York: Springer. 
Schjerning, B. and Le Maire, D. (2007): Earnings, Uncertainty, and the SelfEmployment Choice, Center for Economics and Business Research Discussion Paper 2007-04 04.

Schumpeter, Joseph A. (1939): Business Cycles: A Theoretical, Historical, and Statistical Analysis of the Capitalist Process, New York.

Statistisches Bundesamt (2003): Klassifikation der Wirtschaftszweige mit Erläuterungen, Stuttgart: Metzler-Poeschel.

Statistisches Bundesamt (2004): Fachserie 2, Reihe 5 (Gewerbeanzeigen).

Statistisches Bundesamt (2009): Handbuch zum Mikrozensus-Panel 2001-2004, Wiesbaden: Statistische Bundesamt http://www.gesis.org/download/fileadmin/missy/erhebung/Panel/20012004/MZP0104 Handbuch.pdf

Van Praag, Mirjam and Peter H. Versloot (2007): What is the value of entrepreneurship? A Review of Recent Research, Small Business Economics, 29, 351-382. 


\section{Appendix}

Table A1: Self-employment and start-ups in Germany 1991-2009

\begin{tabular}{|c|c|c|c|c|c|c|c|c|c|c|c|c|}
\hline \multirow[t]{3}{*}{ Year } & \multicolumn{6}{|c|}{ Self-employment } & \multicolumn{6}{|c|}{ Start-ups } \\
\hline & \multicolumn{3}{|c|}{ Number $(1,000)$} & \multicolumn{3}{|c|}{$\begin{array}{l}\text { Self-employment rate } \\
(\%)\end{array}$} & \multicolumn{3}{|c|}{ Number $(1,000)$} & \multicolumn{3}{|c|}{ Start-up rate (\%) } \\
\hline & Overall & West & $\begin{array}{c}\text { East } \\
\text { (incl. } \\
\text { Berlin) }\end{array}$ & Overall & West & \begin{tabular}{|c} 
East \\
(incl. \\
Berlin)
\end{tabular} & Overall & West & $\begin{array}{c}\text { East } \\
\text { (incl. } \\
\text { Berlin) }\end{array}$ & Overall & West & $\begin{array}{c}\text { East } \\
\text { (incl. } \\
\text { Berlin) }\end{array}$ \\
\hline 1991 & 3,037 & 2,594 & 443 & 8.1 & 9.0 & 5.1 & \multirow{5}{*}{\multicolumn{6}{|c|}{ Identification of start-ups is not possible }} \\
\hline 1992 & 3,091 & 2,597 & 494 & 8.3 & 8.9 & 6.4 & & & & & & \\
\hline 1993 & 3,175 & 2,644 & 531 & 8.6 & 9.1 & 7.1 & & & & & & \\
\hline 1994 & 3,288 & \multirow{2}{*}{\multicolumn{5}{|c|}{ Data not available }} & & & & & & \\
\hline 1995 & 3,336 & & & & & & & & & & & \\
\hline 1996 & 3,409 & 2,808 & 600 & 9.4 & 9.8 & 7.9 & 316 & 250 & 66 & 0.9 & 0.9 & 0.9 \\
\hline 1997 & 3,528 & 2,895 & 633 & 9.8 & 1.01 & 8.6 & 341 & 268 & 73 & 1.0 & 1.0 & 1.0 \\
\hline 1998 & 3,594 & 2,940 & 654 & 10.0 & 1.02 & 9.0 & 333 & 259 & 74 & 1.0 & 0.9 & 1.0 \\
\hline 1999 & 3,594 & 2,939 & 655 & 9.8 & 1.01 & 8.9 & 312 & 245 & 67 & 0.9 & 0.9 & 0.9 \\
\hline 2000 & 3,643 & 2,971 & 672 & 9.9 & 1.01 & 9.2 & 324 & 251 & 73 & 0.9 & 0.9 & 1.0 \\
\hline 2001 & 3,632 & 2,959 & 673 & 9.8 & 9.9 & 9.3 & 262 & 200 & 62 & 0.7 & 0.7 & 0.9 \\
\hline 2002 & 3,654 & 2,991 & 664 & 9.9 & 1.01 & 9.3 & 295 & 234 & 61 & 0.8 & 0.8 & 0.9 \\
\hline 2003 & 3,744 & 3,036 & 708 & 1.03 & 1.03 & 1.01 & 327 & 253 & 74 & 0.9 & 0.9 & 1.1 \\
\hline 2004 & 3,852 & 3,100 & 753 & 1.07 & 1.07 & 1.07 & 345 & 260 & 85 & 1.0 & 0.9 & 1.2 \\
\hline 2005 & 4,080 & 3,249 & 831 & 1.10 & 1.09 & 1.17 & 396 & 286 & 110 & 1.1 & 1.0 & 1.6 \\
\hline 2006 & 4,131 & 3,274 & 857 & 1.09 & 1.07 & 1.17 & 360 & 280 & 80 & 1.0 & 0.9 & 1.1 \\
\hline 2007 & 4,160 & 3,308 & 852 & 1.07 & 1.06 & 1.14 & 344 & 272 & 71 & 0.9 & 0.9 & 1.0 \\
\hline 2008 & 4,143 & 3,292 & 851 & 1.07 & 1.05 & 1.13 & 292 & 229 & 63 & 0.8 & 0.8 & 0.9 \\
\hline 2009 & 4,215 & 3,348 & 867 & 1.09 & 1.07 & 1.14 & 294 & 229 & 65 & 0.8 & 0.8 & 0.9 \\
\hline
\end{tabular}


Table A2: Self-employed individuals and business founders with and without employees, 1991-2009

\begin{tabular}{|c|c|c|c|c|c|c|c|c|c|c|}
\hline Year & \multicolumn{5}{|c|}{ Self-employment } & \multicolumn{5}{|c|}{ Start-ups } \\
\hline & Overall & \multicolumn{2}{|c|}{$\begin{array}{c}\text { Without } \\
\text { employees }\end{array}$} & \multicolumn{2}{|c|}{ With employees } & Overall & \multicolumn{2}{|c|}{$\begin{array}{c}\text { Without } \\
\text { employees }\end{array}$} & \multicolumn{2}{|c|}{ With employees } \\
\hline & $\begin{array}{c}\text { Number } \\
(1,000)\end{array}$ & $\begin{array}{c}\text { Number } \\
(1,000)\end{array}$ & $\begin{array}{c}\text { Self- } \\
\text { empl. } \\
\text { rate (\%) }\end{array}$ & $\begin{array}{c}\text { Number } \\
(1,000)\end{array}$ & $\begin{array}{c}\text { Self- } \\
\text { empl. } \\
\text { rate }(\%)\end{array}$ & $\begin{array}{c}\text { Number } \\
(1,000)\end{array}$ & $\begin{array}{c}\text { Number } \\
(1,000)\end{array}$ & $\begin{array}{l}\text { Start-up } \\
\text { rate (\%) }\end{array}$ & $\begin{array}{c}\text { Number } \\
(1,000)\end{array}$ & $\begin{array}{l}\text { Start-up } \\
\text { rate (\%) }\end{array}$ \\
\hline 1991 & 3,037 & 1,383 & 3.7 & 1,654 & 4.4 & \multirow{5}{*}{\multicolumn{5}{|c|}{ Identification of start-ups not possible }} \\
\hline 1992 & 3,091 & 1,378 & 3.7 & 1,713 & 4.6 & & & & & \\
\hline 1993 & 3,175 & 1,412 & 3.8 & 1,763 & 4.8 & & & & & \\
\hline 1994 & 3,288 & \multirow{2}{*}{\multicolumn{4}{|c|}{ Data not available }} & & & & & \\
\hline 1995 & 3,336 & & & & & & & & & \\
\hline 1996 & 3,409 & 1,641 & 4.5 & 1,768 & 4.9 & 316 & 219 & 0.6 & 97 & 0.3 \\
\hline 1997 & 3,528 & 1,752 & 4.8 & 1,776 & 5.0 & 341 & 248 & 0.7 & 93 & 0.3 \\
\hline 1998 & 3,594 & 1,789 & 4.9 & 1,805 & 5.0 & 333 & 233 & 0.7 & 100 & 0.3 \\
\hline 1999 & 3,594 & 1,786 & 4.9 & 1,808 & 5.0 & 312 & 218 & 0.6 & 94 & 0.3 \\
\hline 2000 & 3,643 & 1,842 & 5.0 & 1,801 & 4.9 & 324 & 231 & 0.6 & 93 & 0.3 \\
\hline 2001 & 3,632 & 1,821 & 4.9 & 1,811 & 4.9 & 262 & 184 & 0.5 & 78 & 0.2 \\
\hline 2002 & 3,654 & 1,858 & 5.0 & 1,796 & 4.9 & 295 & 211 & 0.6 & 84 & 0.2 \\
\hline 2003 & 3,744 & 1,960 & 5.4 & 1,784 & 4.9 & 327 & 246 & 0.7 & 81 & 0.2 \\
\hline 2004 & 3,852 & 2,076 & 5.8 & 1,776 & 5.0 & 345 & 272 & 0.8 & 73 & 0.2 \\
\hline 2005 & 4,080 & 2,291 & 6.2 & 1,789 & 4.9 & 396 & 318 & 0.9 & 78 & 0.2 \\
\hline 2006 & 4,131 & 2,317 & 6.1 & 1,814 & 4.8 & 360 & 287 & 0.8 & 73 & 0.2 \\
\hline 2007 & 4,160 & 2,323 & 6.0 & 1,837 & 4.8 & 344 & 272 & 0.7 & 72 & 0.2 \\
\hline 2008 & 4,143 & 2,306 & 5.9 & 1,837 & 4.7 & 292 & 222 & 0.6 & 70 & 0.2 \\
\hline 2009 & 4,215 & 2,356 & 6.1 & 1,859 & 4.8 & 294 & 233 & 0.6 & 62 & 0.2 \\
\hline
\end{tabular}


Table A3: Self-employment and new business formation by industrial sectors, absolute numbers in thousands (first row) and shares in percent (second row), 1991-2009

\begin{tabular}{|c|c|c|c|c|c|}
\hline \multirow{2}{*}{ Industrial sector } & \multicolumn{5}{|c|}{ Self-employment } \\
\hline & 1991 & 1996 & 2000 & 2004 & 2009 \\
\hline \multirow{2}{*}{ Agriculture and forestry } & 415 & 331 & 320 & 289 & 275 \\
\hline & 13.66 & 9.70 & 8.78 & 7.51 & 6.53 \\
\hline \multirow{2}{*}{$\begin{array}{l}\text { Mining, manufacturing, } \\
\text { energy and water supply }\end{array}$} & 480 & 400 & 383 & 377 & 350 \\
\hline & 15.82 & 11.75 & 10.51 & 9.78 & 8.31 \\
\hline \multirow{2}{*}{ Construction } & 243 & 356 & 392 & 391 & 473 \\
\hline & 8.00 & 10.45 & 10.75 & 10.15 & 11.24 \\
\hline \multirow{2}{*}{ Trading and hospitality } & 812 & 938 & 924 & 907 & 884 \\
\hline & 26.74 & 27.52 & 25.36 & 23.54 & 21.01 \\
\hline \multirow{2}{*}{$\begin{array}{l}\text { Transport and } \\
\text { communication }\end{array}$} & 124 & 128 & 150 & 136 & 137 \\
\hline & 4.07 & 3.75 & 4.12 & 3.53 & 3.25 \\
\hline \multirow{2}{*}{ Credit and insurance } & 103 & 111 & 133 & 143 & 153 \\
\hline & 3.40 & 3.25 & 3.66 & 3.72 & 3.64 \\
\hline \multirow{2}{*}{$\begin{array}{l}\text { Renting, business and other } \\
\text { public and private services }\end{array}$} & 860 & 1,144 & 1,342 & 1,609 & 1,936 \\
\hline & 28.32 & 33.58 & 36.82 & 41.78 & 46.02 \\
\hline Total & 3,037 & 3,409 & 3,643 & 3,852 & 4,208 \\
\hline \multirow{2}{*}{ Industrial sector: } & \multicolumn{5}{|c|}{ Start-ups } \\
\hline & \multirow{16}{*}{$\begin{array}{l}\text { Identification } \\
\text { of start-ups } \\
\text { not possible }\end{array}$} & 1996 & 2000 & 2004 & 2009 \\
\hline \multirow{2}{*}{ Agriculture and forestry } & & 11 & 9 & 9 & 8 \\
\hline & & 0.35 & 0.28 & 0.25 & 2.78 \\
\hline \multirow{2}{*}{$\begin{array}{l}\text { Mining, manufacturing, } \\
\text { energy and water supply }\end{array}$} & & 31 & 25 & 24 & 16 \\
\hline & & 1.01 & 0.74 & 0.66 & 5.33 \\
\hline \multirow{2}{*}{ Construction } & & 32 & 34 & 35 & 26 \\
\hline & & 1.04 & 1.01 & 0.96 & 8.82 \\
\hline \multirow{2}{*}{ Trading and hospitality } & & 97 & 83 & 84 & 66 \\
\hline & & 3.19 & 2.44 & 2.29 & 22.65 \\
\hline \multirow{2}{*}{$\begin{array}{l}\text { Transport and } \\
\text { communication }\end{array}$} & & 15 & 16 & 13 & 9 \\
\hline & & 0.49 & 0.47 & 0.35 & 2.99 \\
\hline \multirow{2}{*}{ Credit and insurance } & & 13 & 18 & 18 & 13 \\
\hline & & 0.43 & 0.52 & 0.49 & 4.56 \\
\hline \multirow{2}{*}{$\begin{array}{l}\text { Renting, business and other } \\
\text { public and private services }\end{array}$} & & 118 & 139 & 162 & 155 \\
\hline & & 37.36 & 42.73 & 47.10 & 52.87 \\
\hline Total & & 316 & 324 & 345 & 294 \\
\hline
\end{tabular}


Table A4: Demographic characteristics of self-employed and dependently employed 1991-2009: Gender, age, and marital status (shares and rates in percent)

\begin{tabular}{|c|c|c|c|c|c|c|c|c|c|c|c|c|c|c|c|}
\hline & \multicolumn{3}{|c|}{1991} & \multicolumn{3}{|c|}{1996} & \multicolumn{3}{|c|}{2000} & \multicolumn{3}{|c|}{2004} & \multicolumn{3}{|c|}{2009} \\
\hline & $\begin{array}{l}\text { Self- } \\
\text { empl. }\end{array}$ & $\begin{array}{l}\text { Dep. } \\
\text { empl. }\end{array}$ & \begin{tabular}{|l} 
Self- \\
empl. \\
rate
\end{tabular} & $\begin{array}{l}\text { Self- } \\
\text { empl. }\end{array}$ & $\begin{array}{l}\text { Dep. } \\
\text { empl. }\end{array}$ & $\begin{array}{l}\text { Self- } \\
\text { empl. } \\
\text { rate }\end{array}$ & $\begin{array}{l}\text { Self- } \\
\text { empl. }\end{array}$ & $\begin{array}{l}\text { Dep. } \\
\text { empl. }\end{array}$ & $\begin{array}{l}\text { Self- } \\
\text { empl. } \\
\text { rate }\end{array}$ & $\begin{array}{l}\text { Self- } \\
\text { empl. }\end{array}$ & $\begin{array}{l}\text { Dep. } \\
\text { empl. }\end{array}$ & $\begin{array}{l}\text { Self- } \\
\text { empl. } \\
\text { rate }\end{array}$ & $\begin{array}{l}\text { Self- } \\
\text { empl. }\end{array}$ & $\begin{array}{l}\text { Dep. } \\
\text { empl. }\end{array}$ & $\begin{array}{l}\text { Self- } \\
\text { empl. } \\
\text { rate }\end{array}$ \\
\hline \multicolumn{16}{|c|}{ Gender } \\
\hline Male & 74.33 & 57.01 & 10.32 & 73.12 & 55.92 & 12.04 & 72.23 & 54.76 & 12.72 & 71.13 & 53.26 & 13.92 & 68.89 & 52.45 & 13.85 \\
\hline Female & 25.67 & 42.99 & 5.01 & 26.88 & 44.08 & 6.00 & 27.77 & 45.24 & 6.35 & 28.87 & 46.74 & 6.96 & 31.11 & 47.55 & 7.41 \\
\hline \multicolumn{16}{|c|}{ Age cohorts } \\
\hline$<25$ & 2.73 & 17.15 & 1.39 & 1.57 & 12.88 & 1.26 & 1.48 & 12.96 & 1.25 & 1.55 & 12.39 & 1.49 & 1.53 & 12.46 & 1.48 \\
\hline 25 to 35 & 18.54 & 27.12 & 5.69 & 19.65 & 28.11 & 6.82 & 16.59 & 24.78 & 6.89 & 13.29 & 20.82 & 7.18 & 12.44 & 20.12 & 7.03 \\
\hline 35 to 45 & 27.65 & 23.32 & 9.47 & 29.62 & 26.29 & 10.55 & 31.18 & 28.67 & 10.73 & 32.80 & 30.06 & 11.67 & 29.69 & 26.50 & 12.06 \\
\hline 45 to 55 & 28.98 & 22.93 & 10.03 & 26.68 & 21.21 & 11.63 & 27.23 & 22.04 & 12.02 & 29.12 & 24.59 & 12.54 & 31.27 & 26.12 & 12.78 \\
\hline 55 to 65 & 17.43 & 8.97 & 14.64 & 18.00 & 10.92 & 14.71 & 18.98 & 10.92 & 16.11 & 18.47 & 11.30 & 16.53 & 18.85 & 13.61 & 14.49 \\
\hline$>65$ & 4.67 & 0.52 & 44.40 & 4.47 & 0.60 & 43.83 & 4.53 & 0.63 & 44.35 & 4.77 & 0.84 & 40.85 & 6.22 & 1.18 & 39.21 \\
\hline \multicolumn{16}{|c|}{ Marital status } \\
\hline Single & 24.69 & 37.26 & 5.53 & 27.93 & 38.47 & 7.06 & 29.86 & 40.34 & 7.56 & 32.55 & 41.92 & 8.59 & 36.33 & 46.06 & 8.80 \\
\hline Married & 75.31 & 62.74 & 9.58 & 72.07 & 61.53 & 10.92 & 70.13 & 59.66 & 11.50 & 67.45 & 58.08 & 12.33 & 63.67 & 53.94 & 12.62 \\
\hline \multicolumn{16}{|c|}{ Nationality } \\
\hline $\begin{array}{l}\text { German incl. } \\
\text { multiple } \\
\text { nationality }\end{array}$ & 94.26 & 92.92 & 8.22 & 92.65 & 91.76 & 9.56 & 92.94 & 91.64 & 10.08 & 92.30 & 91.71 & 10.87 & 90.34 & 91.44 & 10.79 \\
\hline Non-german & 5.74 & 7.08 & 6.68 & 7.35 & 8.24 & 8.54 & 7.06 & 8.36 & 8.54 & 7.70 & 8.29 & 10.11 & 9.66 & 8.56 & 12.13 \\
\hline Total & 3,037 & 34,408 & - & 3,409 & 32,574 & - & 3,643 & 32,960 & - & 3,852 & 31,807 & - & 4,215 & 34,447 & - \\
\hline
\end{tabular}


Table A5: Demographic characteristics of new business founders: gender, age, marital status, and nationality, 1996-2009.

\begin{tabular}{|c|c|c|c|c|c|c|c|c|}
\hline & \multicolumn{2}{|c|}{1996} & \multicolumn{2}{|c|}{2000} & \multicolumn{2}{|c|}{2004} & \multicolumn{2}{|c|}{2009} \\
\hline & $\begin{array}{l}\text { Share of } \\
\text { founders }\end{array}$ & $\begin{array}{l}\text { Start-up } \\
\text { rate }\end{array}$ & $\begin{array}{l}\text { Share of } \\
\text { founders }\end{array}$ & $\begin{array}{l}\text { Start-up } \\
\text { rate }\end{array}$ & $\begin{array}{l}\text { Share of } \\
\text { founders }\end{array}$ & $\begin{array}{l}\text { Start-up } \\
\text { rate }\end{array}$ & $\begin{array}{l}\text { Share of } \\
\text { founders }\end{array}$ & $\begin{array}{l}\text { Start-up } \\
\text { rate }\end{array}$ \\
\hline \multicolumn{9}{|c|}{ Gender } \\
\hline Male & 66.69 & 1.02 & 64.61 & 1.01 & 63.46 & 1.11 & 58.41 & 0.82 \\
\hline Female & 33.31 & 0.69 & 35.39 & 0.72 & 36.54 & 0.79 & 41.59 & 0.69 \\
\hline \multicolumn{9}{|c|}{ Age cohorts } \\
\hline$<25$ & 7.09 & 0.53 & 7.13 & 0.53 & 7.61 & 0.66 & 9.22 & 0.62 \\
\hline 25 to 35 & 42.65 & 1.37 & 36.44 & 1.35 & 30.37 & 1.47 & 31.43 & 1.24 \\
\hline 35 to 45 & 29.92 & 0.99 & 34.34 & 1.05 & 36.67 & 1.17 & 32.66 & 0.93 \\
\hline 45 to 55 & 15.50 & 0.63 & 15.89 & 0.62 & 18.54 & 0.71 & 18.96 & 0.54 \\
\hline 55 to 65 & 3.93 & 0.30 & 4.95 & 0.37 & 5.70 & 0.46 & 6.05 & 0.32 \\
\hline$>65$ & 0.91 & 0.83 & 1.25 & 1.09 & 1.10 & 0.85 & 1.69 & 0.74 \\
\hline \multicolumn{9}{|c|}{ Marital status } \\
\hline Single & 43.61 & 1.02 & 44.13 & 0.99 & 47.35 & 1.12 & 52.48 & 0.89 \\
\hline Married & 56.39 & 0.79 & 55.87 & 0.82 & 52.65 & 0.86 & 47.52 & 0.66 \\
\hline \multicolumn{9}{|c|}{ Nationality } \\
\hline \begin{tabular}{|l|} 
German \\
incl. multiple \\
nationality
\end{tabular} & 87.23 & 0.85 & 88.12 & 0.87 & 88.11 & 0.95 & 82.82 & 0.71 \\
\hline Non-german & 12.77 & 1.39 & 11.88 & 1.30 & 11.89 & 1.40 & 17.18 & 1.55 \\
\hline Total & 316 & - & 324 & - & 345 & - & 294 & - \\
\hline
\end{tabular}


Table A6: Self-employed and the highest level of education

\begin{tabular}{|c|c|c|c|c|c|c|c|}
\hline \multirow[t]{2}{*}{ Year } & \multicolumn{2}{|c|}{ Vocational education } & \multicolumn{2}{|c|}{ Tertiary education } & \multicolumn{2}{|c|}{$\begin{array}{l}\text { Without educational } \\
\text { level or not reported }\end{array}$} & \multirow{2}{*}{$\begin{array}{c}\text { Total }^{*} \\
\begin{array}{c}\text { Number } \\
(1,000)\end{array}\end{array}$} \\
\hline & $\begin{array}{l}\text { Number } \\
(1,000)\end{array}$ & $\begin{array}{c}\text { Self- } \\
\text { empl. } \\
\text { rate }(\%)\end{array}$ & $\begin{array}{c}\text { Number } \\
(1,000)\end{array}$ & $\begin{array}{c}\text { Self- } \\
\text { empl. } \\
\text { rate }(\%)\end{array}$ & $\begin{array}{c}\text { Number } \\
(1,000)\end{array}$ & $\begin{array}{c}\text { Self- } \\
\text { empl. } \\
\text { rate }(\%)\end{array}$ & \\
\hline 1991 & 1,894 & 7.78 & 501 & 12.35 & 319 & 5.71 & 2,714 \\
\hline 1993 & 1,914 & 8.29 & 611 & 13.86 & 312 & 5.77 & 2,837 \\
\hline 1996 & 2,042 & 8.76 & 784 & 15.04 & 583 & 5.93 & 3,409 \\
\hline 1997 & 2,144 & 9.10 & 857 & 15.91 & 527 & 5.96 & 3,528 \\
\hline 1998 & 2,176 & 9.23 & 888 & 16.00 & 530 & 6.01 & 3,594 \\
\hline 1999 & 2,163 & 9.18 & 848 & 16.42 & 584 & 5.74 & 3,594 \\
\hline 2000 & 2,113 & 9.10 & 882 & 16.83 & 648 & 5.62 & 3,643 \\
\hline 2001 & 2,157 & 9.10 & 883 & 16.58 & 592 & 5.43 & 3,632 \\
\hline 2002 & 2,162 & 9.22 & 928 & 17.00 & 564 & 5.29 & 3,654 \\
\hline 2003 & 2,170 & 9.44 & 975 & 17.61 & 599 & 5.70 & 3,744 \\
\hline 2004 & 2,182 & 9.73 & 1,022 & 18.18 & 648 & 6.08 & 3,852 \\
\hline 2005 & 2,484 & 10.26 & 1,123 & 18.78 & 472 & 6.87 & 4,080 \\
\hline 2006 & 2,494 & 10.11 & 1,141 & 18.48 & 496 & 6.91 & 4,131 \\
\hline 2007 & 2,517 & 9.90 & 1,164 & 18.09 & 478 & 6.78 & 4,160 \\
\hline 2008 & 2,490 & 9.75 & 1,206 & 17.76 & 447 & 6.64 & 4,143 \\
\hline 2009 & 2,515 & 9.85 & 1,253 & 17.84 & 418 & 6.98 & 4,187 \\
\hline
\end{tabular}

* Total numbers might slightly deviate from the total number of self-employed in other tables due to voluntary response on the question about the highest level of education. Numbers for waves before 1996 indicate the last achieved level of education. 
Table A7: Founders and the highest level of education

\begin{tabular}{|c|c|c|c|c|c|c|c|}
\hline \multirow[t]{2}{*}{ Year } & \multicolumn{2}{|c|}{ Vocational education } & \multicolumn{2}{|c|}{ Tertiary education } & \multicolumn{2}{|c|}{$\begin{array}{l}\text { Without educational } \\
\text { level or not reported }\end{array}$} & \multirow{2}{*}{$\begin{array}{c}\text { Total }^{*} \\
\begin{array}{c}\text { Number } \\
\text { (thousands) }\end{array}\end{array}$} \\
\hline & $\begin{array}{c}\text { Number } \\
\text { (thousands) }\end{array}$ & $\begin{array}{l}\text { Start-up } \\
\text { rate (\%) }\end{array}$ & $\begin{array}{c}\text { Number } \\
\text { (thousands) }\end{array}$ & $\begin{array}{l}\text { Start-up } \\
\text { rate (\%) }\end{array}$ & $\begin{array}{c}\text { Number } \\
\text { (thousands) }\end{array}$ & $\begin{array}{l}\text { Start-up } \\
\text { rate (\%) }\end{array}$ & \\
\hline 1996 & 185 & 0.81 & 73 & 1.46 & 58 & 0.65 & 316 \\
\hline 1997 & 202 & 0.88 & 84 & 1.62 & 55 & 0.76 & 341 \\
\hline 1998 & 193 & 0.84 & 84 & 1.58 & 56 & 0.75 & 333 \\
\hline 1999 & 182 & 0.79 & 73 & 1.46 & 57 & 0.76 & 312 \\
\hline 2000 & 183 & 0.81 & 76 & 1.49 & 65 & 0.80 & 324 \\
\hline 2001 & 151 & 0.65 & 58 & 1.12 & 53 & 0.67 & 262 \\
\hline 2002 & 169 & 0.74 & 66 & 1.27 & 59 & 0.79 & 295 \\
\hline 2003 & 190 & 0.85 & 76 & 1.42 & 61 & 0.75 & 327 \\
\hline 2004 & 195 & 0.90 & 82 & 1.50 & 68 & 0.88 & 345 \\
\hline 2005 & 242 & 1.03 & 93 & 1.63 & 61 & 0.93 & 396 \\
\hline 2006 & 209 & 0.88 & 87 & 1.45 & 64 & 0.94 & 360 \\
\hline 2007 & 199 & 0.81 & 83 & 1.35 & 63 & 0.93 & 344 \\
\hline 2008 & 159 & 0.65 & 80 & 1.23 & 54 & 0.86 & 292 \\
\hline 2009 & 165 & 0.68 & 75 & 1.13 & 50 & 0.87 & 291 \\
\hline
\end{tabular}

${ }^{*}$ Total numbers might slightly deviate from the total number of self-employed in other tables due to voluntary response on the question about the highest level of education. 
Table A8: Determinants of self-employment: logit analyses - East Germany

\begin{tabular}{|c|c|c|c|c|}
\hline & \multicolumn{2}{|c|}{1991} & \multicolumn{2}{|c|}{2009} \\
\hline & Coefficient & $\begin{array}{c}\text { Marginal } \\
\text { fixed effect }\end{array}$ & Coefficient & $\begin{array}{l}\text { Marginal } \\
\text { fixed effect }\end{array}$ \\
\hline \multirow[t]{2}{*}{ Age } & $0.085^{\star * *}$ & $0.003^{\star \star}$ & $0.099^{* * *}$ & $0.008^{* * *}$ \\
\hline & $(0.013)$ & $(0.001)$ & $(0.008)$ & $(0.001)$ \\
\hline \multirow[t]{2}{*}{ Age, squared } & $-0.001^{* * *}$ & $-0.00003^{* * *}$ & $-0.0008^{* * *}$ & $-0.0001^{* * *}$ \\
\hline & $(0.0002)$ & $(0.0001)$ & $(0.0001)$ & $(0.00001)$ \\
\hline \multirow[t]{2}{*}{ Married } & -0.001 & -0.00005 & $-0.065^{\star \star}$ & $-0.005^{\star *}$ \\
\hline & $(0.043)$ & $(0.002)$ & $(0.029)$ & $(0.002)$ \\
\hline \multirow[t]{2}{*}{ Female } & $-1.032^{\star * *}$ & $-0.039^{* * *}$ & $-0.868^{\star * *}$ & $-0.073^{* * *}$ \\
\hline & $(0.038)$ & $(0.001)$ & $(0.027)$ & $(0.002)$ \\
\hline \multirow[t]{2}{*}{$\begin{array}{l}\text { German } \\
\text { nationality }\end{array}$} & $-0.440^{* \star *}$ & $-0.020^{* * *}$ & $-0.673^{* * *}$ & $-0.073^{* * *}$ \\
\hline & $(0.116)$ & $(0.006)$ & $(0.066)$ & $(0.009)$ \\
\hline \multirow{2}{*}{$\begin{array}{l}\text { Service sector } \\
\text { employment }\end{array}$} & $0.966^{\star * *}$ & $0.036^{\star * *}$ & $0.845^{\star * *}$ & $0.066^{\star * *}$ \\
\hline & $(0.037)$ & $(0.001)$ & (0.029) & $(0.002)$ \\
\hline $\begin{array}{l}\text { Vocational } \\
\text { training }\end{array}$ & $\begin{array}{l}0.542^{* * *} \\
(0.087)\end{array}$ & $\begin{array}{l}0.017^{* * *} \\
(0.002)\end{array}$ & $\begin{array}{l}0.137^{\star *} \\
(0.056)\end{array}$ & $\begin{array}{l}0.011^{* *} \\
(0.005)\end{array}$ \\
\hline $\begin{array}{l}\text { Tertiary } \\
\text { education }\end{array}$ & $\begin{array}{l}0.814^{\star * *} \\
(0.095)\end{array}$ & $\begin{array}{l}0.042^{* * *} \\
(0.006)\end{array}$ & $\begin{array}{l}0.890^{\star * *} \\
(0.058)\end{array}$ & $\begin{array}{l}0.095^{\star \star *} \\
(0.007)\end{array}$ \\
\hline \multirow[t]{2}{*}{ Intercept } & $-5.349^{* * *}$ & & $-4.573^{* * *}$ & \\
\hline & $(0.269)$ & & $(0.174)$ & \\
\hline Pseudo R2 & 0.0598 & & 0.0768 & \\
\hline Log Likelihood & -13998.178 & & -20506.242 & \\
\hline Wald Chi2 & $1920.46^{\star \star \star}$ & & $3453.57^{\star * *}$ & \\
\hline $\begin{array}{l}\text { Number of } \\
\text { observations }\end{array}$ & 75,407 & & 63,172 & \\
\hline
\end{tabular}

Note: Dependent variable: self-employment status $(1=$ yes; $0=$ no). ${ }^{* * *}$ : statistically significant at the 1 percent level; ${ }^{* *}$ : statistically significant at the 5 percent level; *: statistically significant at the 10 percent level. 
Table A9: Determinants of self-employment (logit analyses) - West Germany

\begin{tabular}{|c|c|c|c|c|}
\hline & \multicolumn{2}{|c|}{1991} & \multicolumn{2}{|c|}{2009} \\
\hline & Coefficient & $\begin{array}{c}\text { Marginal } \\
\text { fixed effect }\end{array}$ & Coefficient & $\begin{array}{c}\text { Marginal } \\
\text { fixed effect }\end{array}$ \\
\hline \multirow[t]{2}{*}{ Age } & $0.050^{* * *}$ & $0.003^{* * *}$ & $0.083^{* * *}$ & $.006^{* * *}$ \\
\hline & $(0.004)$ & $(0.0003)$ & $(0.004)$ & $(0.0003)$ \\
\hline \multirow[t]{2}{*}{ Age, squared } & -0.00001 & -0.00001 & $-0.0004^{* * *}$ & $-0.00003^{* * *}$ \\
\hline & $(0.00004)$ & $(0.000)$ & $(0.00004)$ & $(0.000)$ \\
\hline \multirow[t]{2}{*}{ Married } & $0.091^{* * *}$ & $0.006^{* * *}$ & -0.004 & -0.0003 \\
\hline & $(0.019)$ & $(0.001)$ & $(0.015)$ & $(0.001)$ \\
\hline \multirow[t]{2}{*}{ Female } & $-0.721^{* * *}$ & $-0.046^{* * *}$ & $-0.874^{* * *}$ & $-0.067^{* * *}$ \\
\hline & $(0.017)$ & $(0.001)$ & $(0.014)$ & $(0.001)$ \\
\hline \multirow[t]{2}{*}{$\begin{array}{l}\text { German } \\
\text { nationality }\end{array}$} & $0.204^{\star \star \star}$ & $0.013^{\star * *}$ & $-0.199^{\star \star \star}$ & $-0.016^{\star \star \star}$ \\
\hline & $(0.035)$ & $(0.002)$ & $(0.025)$ & (0.002) \\
\hline \multirow{2}{*}{$\begin{array}{l}\text { Service sector } \\
\text { employment }\end{array}$} & $0.375^{\star \star \star}$ & $0.025^{\star * *}$ & $0.852^{* * *}$ & $0.063^{* * *}$ \\
\hline & $(0.015)$ & $(0.001)$ & $(0.015)$ & $(0.001)$ \\
\hline $\begin{array}{l}\text { Vocational } \\
\text { training }\end{array}$ & $\begin{array}{c}0.298^{\star * *} \\
(0.023)\end{array}$ & $\begin{array}{c}0.019^{\star * *} \\
(0.001)\end{array}$ & $\begin{array}{c}0.356^{\star \star *} \\
(0.023)\end{array}$ & $\begin{array}{c}0.026^{\star * *} \\
(0.002)\end{array}$ \\
\hline $\begin{array}{l}\text { Tertiary } \\
\text { education }\end{array}$ & $\begin{array}{l}0.548^{* * *} \\
(0.029)\end{array}$ & $\begin{array}{l}0.044^{* * *} \\
(0.003)\end{array}$ & $\begin{array}{l}0.829^{\star * *} \\
(0.025)\end{array}$ & $\begin{array}{l}0.081^{* * *} \\
(0.003)\end{array}$ \\
\hline \multirow[t]{2}{*}{ Intercept } & $-4.906^{\star * *}$ & & $-5.321^{* * *}$ & \\
\hline & $(0.085)$ & & $(0.080)$ & \\
\hline Pseudo R2 & 0.0758 & & 0.0889 & \\
\hline Log Likelihood & -64977.211 & & -79647.164 & \\
\hline Wald Chi2 & $11044.06^{* * *}$ & & $14712.46^{\star * *}$ & \\
\hline $\begin{array}{l}\text { Number of } \\
\text { observations }\end{array}$ & 230797 & & 253514 & \\
\hline
\end{tabular}

Note: Dependent variable: self-employment status $\left(1=\right.$ yes; $0=$ no). ${ }^{* * *}$ : statistically significant at the 1 percent level; ${ }^{* *}$ : statistically significant at the 5 percent level; *: statistically significant at the 10 percent level. 